\title{
FRESKEN DES SCHÖNEN STILS IN DER PFARRKIRCHE VON TORNA (HEUTE TURŇA NAD BODVOU, SLOWAKEI) IM EINSTIGEN OBERUNGARN
}

\author{
An O. Univ.-Prof. Dr. Michael Viktor Schwarz \\ zu seinem Ehrentag mit herzlichen Glückwünschen
}

\begin{abstract}
Mural paintings of the International Gothic style in the parish church of Torna (today: Turňa nad Bodvou, Slovakia). The study gives as an introduction a short survey of the medieval history of the Hungarian Kingdom. It introduces the mural paintings of the sanctuary of the village church of Torna, which came to light between 2007 and 2014. The author emphasizes their high artistic level and presents their artistic context in Hungary. The patron of the village and the church after 1409 was Paulus Özdögei Besenyô. He was an outstanding person of the Hungarian royal court and a member of the Order of the Dragon of King Sigismund of Luxembourg. He was the donor of the painted decoration of the church of Torna. The author dates the frescoes between the years of 1410-1414.
\end{abstract}

Keywords: mural painting, Torna, Turňa nad Bodvou, International Gothic style, iconography of angels and saints in the Middle Ages, history of Hungary

Das Königreich Ungarn wurde im Jahr 1000 vom Heiligen Stephan, dem Sohn des Arpadenfürsten Géza, im Karpatenbecken gegründet - anlässlich dessen wurde er in der Kathedrale von Esztergom durch den Erzbischof von Esztergom zum König gekrönt. Ungarn ist also bereits damals staatlich und auch kirchlich ein unabhängiges, starkes und zentralisiertes Königtum an der Grenze des Heiligen Römischen Reiches gewesen. Das weltliche und kirchliche Zentrum des Landes war bis 1256 Esztergom an der Donau. Letztere als eine der größten Flüsse Europas sicherte die unmittelbare Verbindung mit West- und Osteuropa. 1256 verließ der König Esztergom und baute etwas weiter flussabwärts die neue Hauptstadt Buda auf.

Das Königreich Ungarn war von 1000 bis 1526, bis zur Eroberung des Landes durch die Osmanen, eines der mächtigsten Länder Europas. Dies beweisen unter anderem die vielseitigen dynastischen Beziehungen, welche die größten europäischen Herrscherfami-

\footnotetext{
* Prof. emerita Mária Prokopp, Institute of Art History, University Eötvös Loránd, Budapest; mariaprokopp2@gmail.com
}

lien mit der Arpaden-Dynastie schlossen. Wir sollen hier nur einige Bespiele erwähnen. Gisela, die Gattin des ungarischen Königs Stephan (997/1000-1038), war die Schwester des römisch-deutschen Kaisers Heinrich II. König Ladislaus der Heilige (1077-1095) heiratete die Tochter des deutschen Gegenkönigs Rudolf. Die Frau von König Salamon (1064-1074) war Judit, die Schwester des Kaisers Heinrich IV. Die Tochter des Königs Ladislaus, Piroska (1088-1134), war die Gattin des byzantinischen Kaisers Johannes Komnenos mit dem Namen Irene. Die Frau des Königs Koloman (1095-1116), Felicia (Buzilla), war die Tochter des normannischen Herrschers Roger I. König Béla III. (1172-1196) hatte die Schwester des französischen Königs Philipp August, Margarete Capet, im Jahr 1086 geheiratet. Seine Tochter Margarete war als Frau des Kaisers Isakios byzantinische Kaiserin geworden. Die Gattin von König Béla IV. (1235-1270) war Maria Laskaris (1220-1270), die Tochter des byzantinischen Kaisers Theodor I. von Nikaia. Karl I. von Anjou wandte sich, gleich nachdem er das Königreich Sizilien nach einem fünfzehnjährigen Krieg 1265 erhalten hatte, an den ungarischen König Béla IV., da 


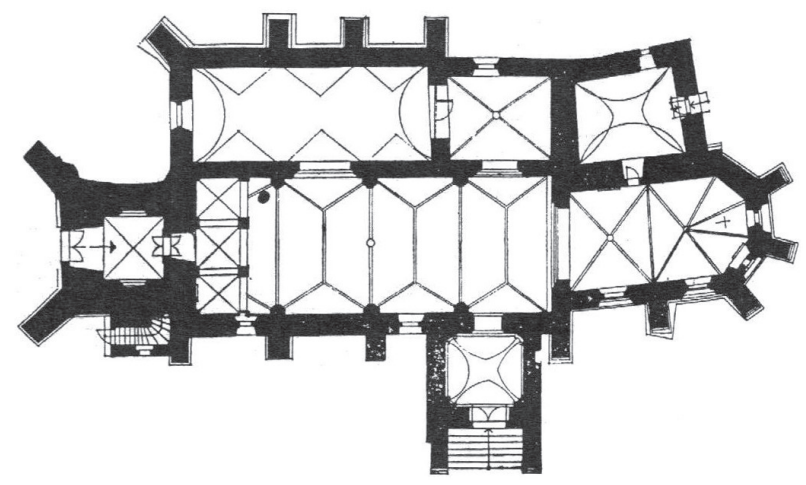

Abb. 1. Der Grundriss der Pfarrkirche von Torna (Turňa nad Bodvou)

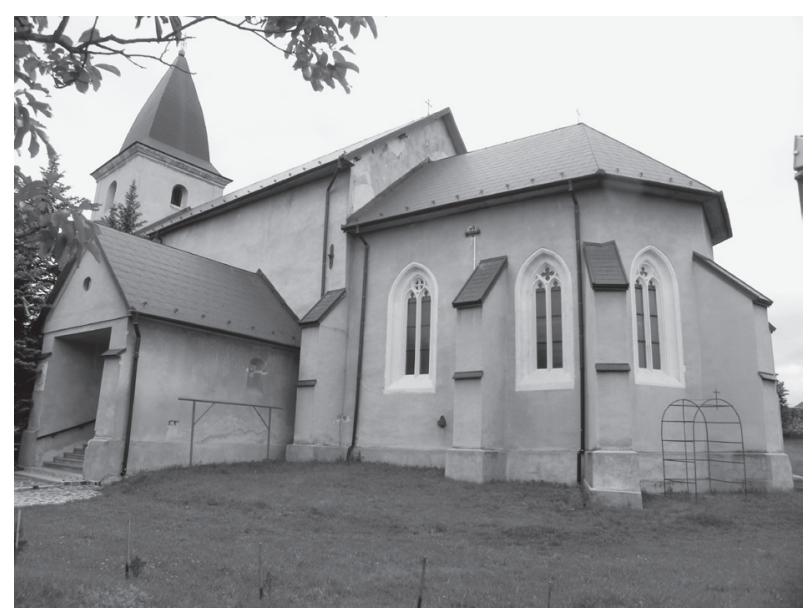

$A b b$. 2. Die Pfarrkirche von Torna von Südosten (Foto: Edit Szentesi, 2013)

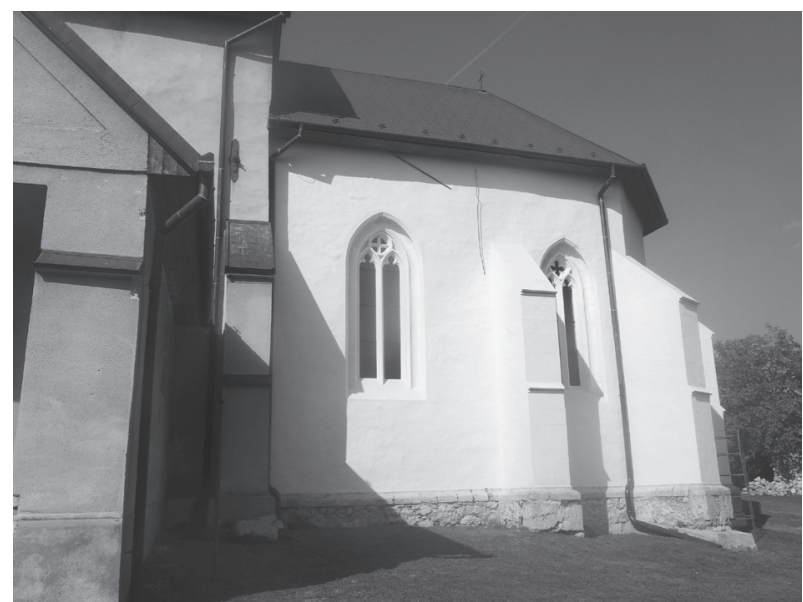

$A b b$. 3. Torna, Pfarrkirche, der Chor von Süden nach der Restaurierung (Foto: Pál Lôvei, 2017)

er als Witwer eine ungarische Königstochter heiraten wollte. Er hielt vier Jahre lang um die Hände von einer seiner Töchter an, aber keine sagte zu. Nach Bélas Tod wandte sich König Karl I. von Anjou 1270 an seinen Sohn, König Stephan V. (1270-1272). Dieser gab seine erstgeborene Tochter Maria mit großer Freude

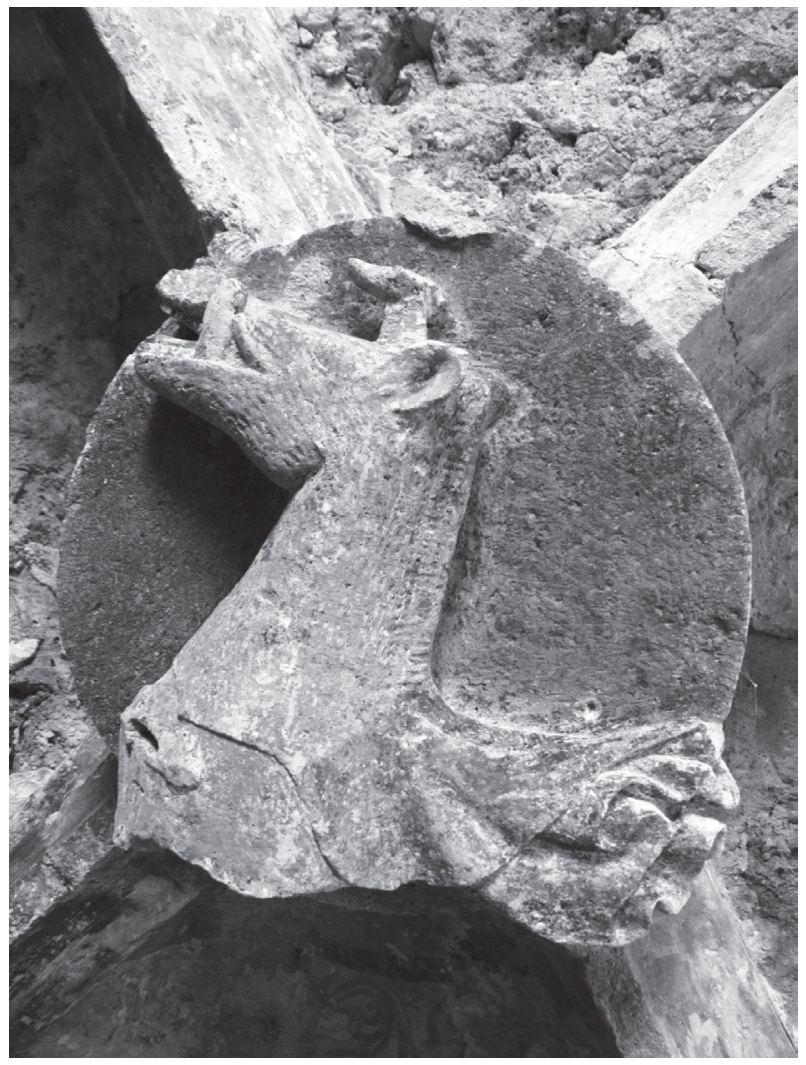

Abb. 4. Torna, Pfarrkirche, Schlussstein im Chor mit der Helmzier der Familie Tornai (Foto: Pál Lóvei, 2011)

an Karls Sohn, den späteren neapolitanischen König Karl II. von Anjou, zur Frau. Karl I. von Anjou bestätigte die ungarischen Beziehungen 1270 mit einer Doppelhochzeit: Seine Tochter Elisabeth wurde die Frau von König Stephans Sohn, dem späteren König Ladislaus IV. (1272-1290). Maria lebte 53 Jahre lang in Neapel und sie gebar ihrem Ehemann dreizehn Kinder. Der Erstgeborene war Karl Martell (1271-1295), dem Dante Alighieri den achten Gesang des Paradiso gewidmet hat. 1308 hat der Sohn von Karl Martell, das Enkelkind der neapolitanischen Königin Maria von Ungarn, als Karl I. von Anjou (1301-1342) die ungarische Krone erhalten. Er und sein Sohn, Ludwig der Große (1342-1382), hatten ihre Frauen aus mitteleuropäischen Dynastien gewählt. Durch seine Heirat mit der Anjou-Königstochter Maria wurde schließlich Sigismund von Luxemburg 1387 zum König von Ungarn. Sigismund regierte fünfzig Jahre lang in Ungarn. 1410 wurde er auch zum deutschen König gewählt und 1433 wurde er in Rom von Papst Eugen IV. als römisch-deutscher Kaiser gekrönt. Seine engsten Begleiter waren - auch in seinen kaiserlichen Höfen - ungarische Würdenträger.

Die vielseitigen dynastischen Verbindungen beweisen, wie hoch die europäischen Herrscher Ungarn 


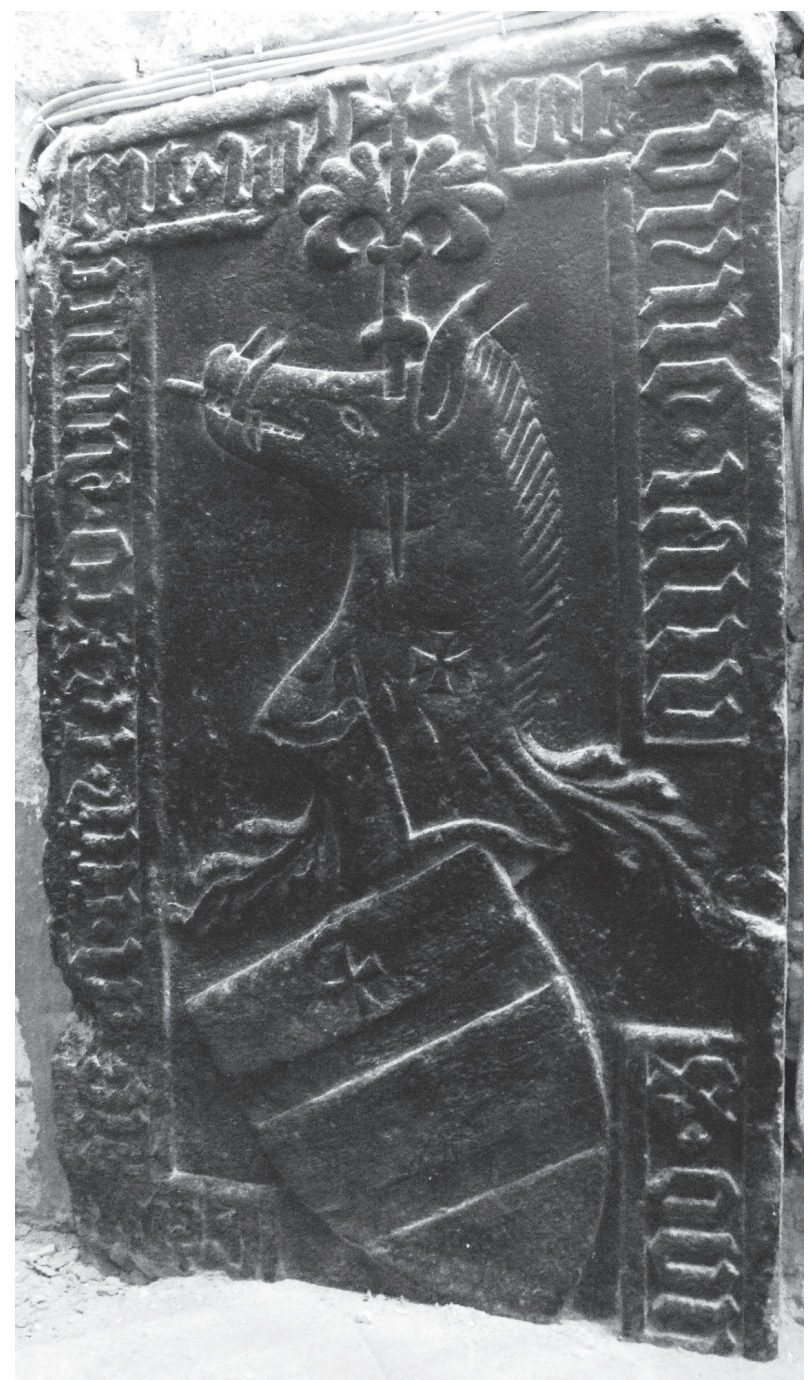

Abb. 5. Torna, Pfarrkirche, die Grabplatte von Johannes Tornai (†1406) (Foto: Pál Lốvei, 2011)

geschätzt haben. Außer den politischen Gründen stellten auch die vielen Bodenschätze und Naturressourcen - Gold, Silber, Eisenerz, Salz, Holz usw. - eine große Anziehungskraft für die Herrscher Europas dar.

Das Königreich Ungarn bestand von 1000 bis 1920 fast tausend Jahre lang und hat das ganze Gebiet des Karpatenbeckens umfasst. Die Stadt Torna befand sich im nordöstlichen Teil des Karpatenbeckens, am Ufer des Flusses Bódva, wo der Weg nach Polen führte. Sie war Sitz des Komitats Torna, der vom 13. Jahrhundert bis 1881 existierte, dann aber mit dem Komitat Abaúj vereinigt wurde. Hoch über der Stadt Torna erhebt sich eine Burgruine, die aus dem 14. Jahrhundert stammt. Der ungarische König Ludwig I. (der Große) von Anjou hatte 1357 Erlaubnis zur Errichtung einer aus Stein erbauten Anlage an den Herren Ägidius und Ludovicus von Torna erteilt. ${ }^{1}$

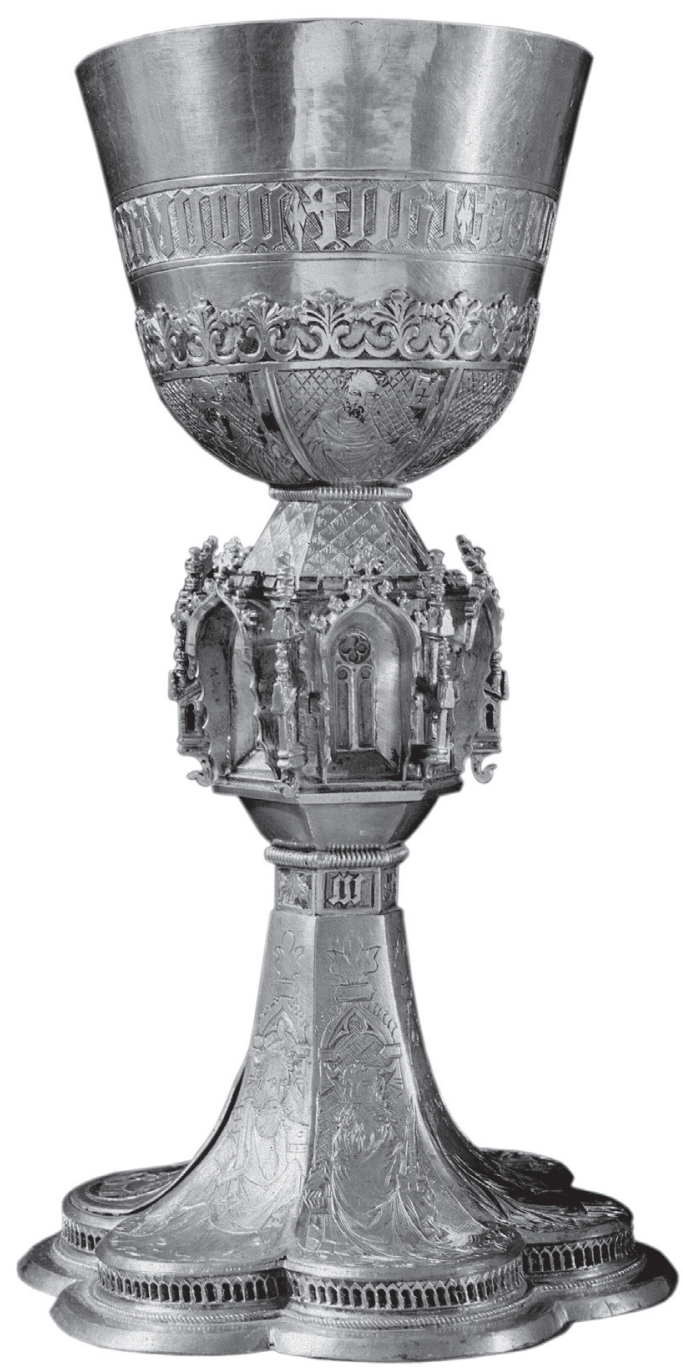

Abb. 6. Der gotische Kelch von Torna. Budapest, Ungarisches Nationalmuseum (Foto: Ungarisches Nationalmuseum)

Die am Fuß der Burg stehende Pfarrkirche Hl. Ägidius wurde aber bereits früher, im 13. Jahrhundert, errichtet ${ }^{2}$ und hatte einen Chor mit geradem Abschluss, wie es die Ausgrabungen im Chor von 2004-2007 festgestellt haben. Im 14. Jahrhundert wurde dann der Chor in gotischem Stil erweitert. Damals hatte er seine heutige Form erhalten und wurde zu einem großen zweijochigen, kreuzgratgewölbten Raum umgebaut, der mit drei Seiten eines Achtecks endet (Abb. 1-3). Er wurde von Osten und Süden durch gotische Fenster beleuchtet. Diese gotische Wehrkirche steht am höchsten Punkt der Siedlung und ist mit Mauern umgeben. Sie wurde bereits 1274 als Pfarrei erwähnt. Die Pfarrei von Torna war eine königliche Stiftung, die mit mehreren Privilegien ausgestattet war. Die Urkunde von König Béla IV aus 1263 erlaubt dem Pfarrer von Torna, den ganzen 


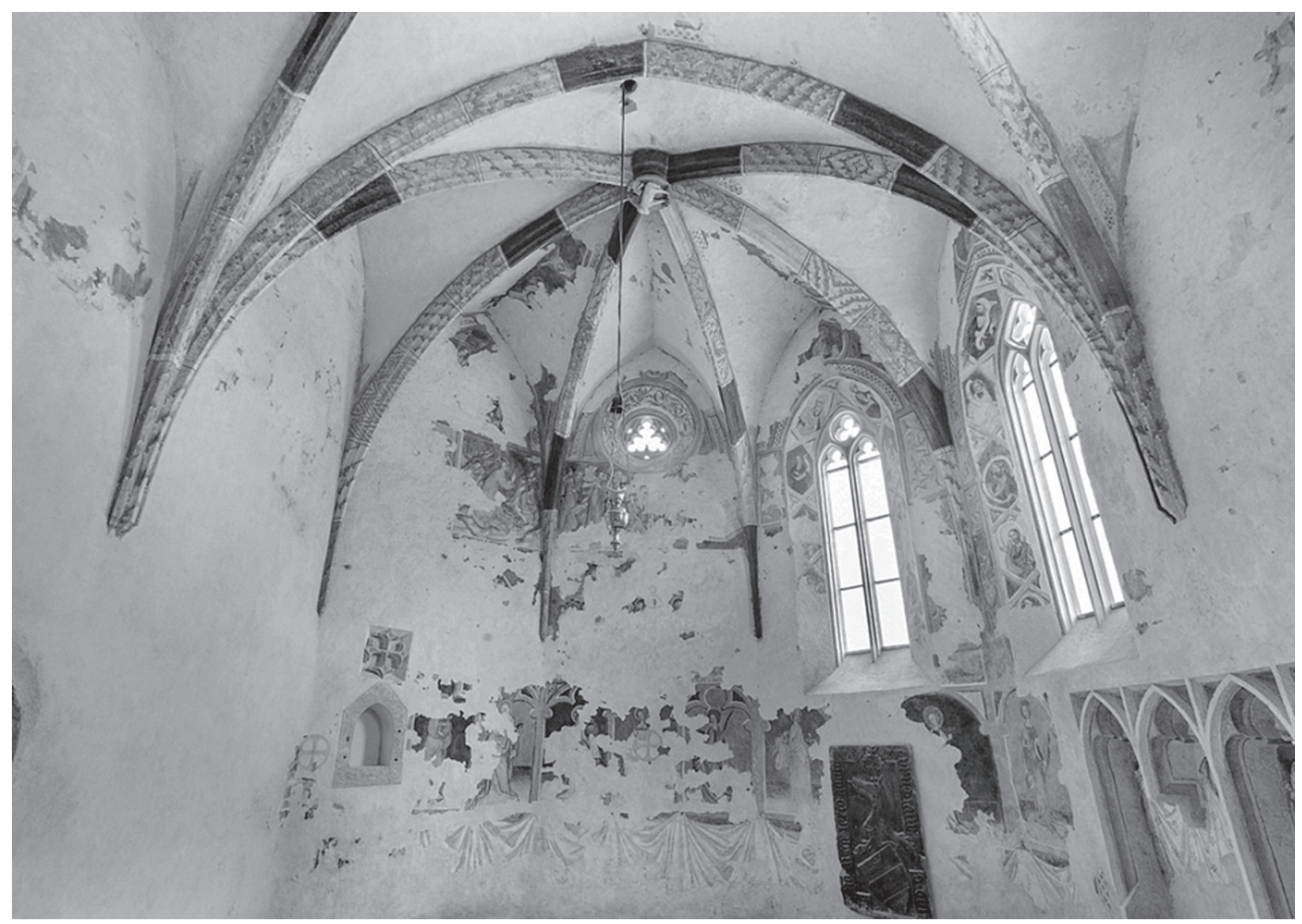

Abb. 7. Torna, Pfarrkirche, die Fresken im Chor, nach der Restaurierung

Zehnt zu behalten. Torna gehörte zur Diözese Esztergom (Gran), die „Caput, Mater et Magistra Ecclesiarum Hungariae" war. Die Erzdiözese Esztergom enthielt von 1000 bis 1777 den größten Teil des Gebiets von Oberungarn am linken Ufer der Donau, von Posonia (Pressburg, Pozsony, heute Bratislava, Slowakei) bis Capitulum Scepesiense (Szepeskáptalan, heute Spisské Kapitula, Slowakei). Der Erzbischof von Esztergom - der Primas von Ungarn - war für die ganze Kirche in Ungarn verantwortlich. Er war der erste Mann des Landes nach dem König.

Die gotische Pfarrkirche in Torna ließ die Familie Torna in der zweiten Hälfte des 13. Jahrhunderts bauen, dann im 14. Jahrhundert in gotischem Stil erweitern. Der Schlussstein am Gewölbe zeigt das Wappen der Familie Tornai, einen Eberkopf (Abb. 4). Die Familie Tornai starb im Jahr 1406 aus. Der Grabstein des Herrn Johannes Tornai $(† 1406)$ lag ursprünglich am Fußboden, heute befindet er sich aber eingemauert in der Ostwand des Chors. ${ }^{3}$ Die Inschrift mit gotischen Minuskeln gibt den Namen und das Sterbejahr an: hit [sic!] iacet tvrne ianvs obiit anno $m$ cccc sexto... (Abb. 5). Der Grabstein ist aus
Trachyt und hat eine Größe von $165 \times 99 \mathrm{~cm}$. Das Wappen der Familie Tornai füllt die gesamte Oberfläche des Grabsteins: Oberhalb vom Wappenschild ist ein Helmbusch mit einem Eberkopf zu sehen, der am Stirn senkrecht von einem Dolch durchstochen wird. Aus dem Griff des Dolches wächst ein Helmbusch hervor, in dessen Mitte ein Kreuz mit sich verdickenden Armen ist. In dem (heraldisch) nach rechts neigenden Schild selbst sind zwei schmale Binden; über dem ersten befindet sich in der Mitte ebenfalls ein Kreuz mit sich verdickenden Armen.

Seit 1409 war der neue Besitzer des Oppidum Torna der Herr Paulus Özdögei Besenyổ (†1432/1434), Mitglied des 1408 von König Sigismund von Luxemburg (1387-1437) gestifteten Drachenordens. Er wurde 1402 von König Sigismund zum Banus von Kroatien und Slawonien ernannt und war ein sehr einflussreicher Mann am Königshof. Er nahm den Namen „von Torna" (Tornai) an. ${ }^{4}$ Wir nehmen an, dass er die Fresken in der Kirche unmittelbar nach Erlangung der Siedlung Torna, also um 1410-1414, hatte malen lassen. Er schenkte auch einen prachtvollen Kelch mit der Darstellung der Hl. Barbara und seinem Wappen 


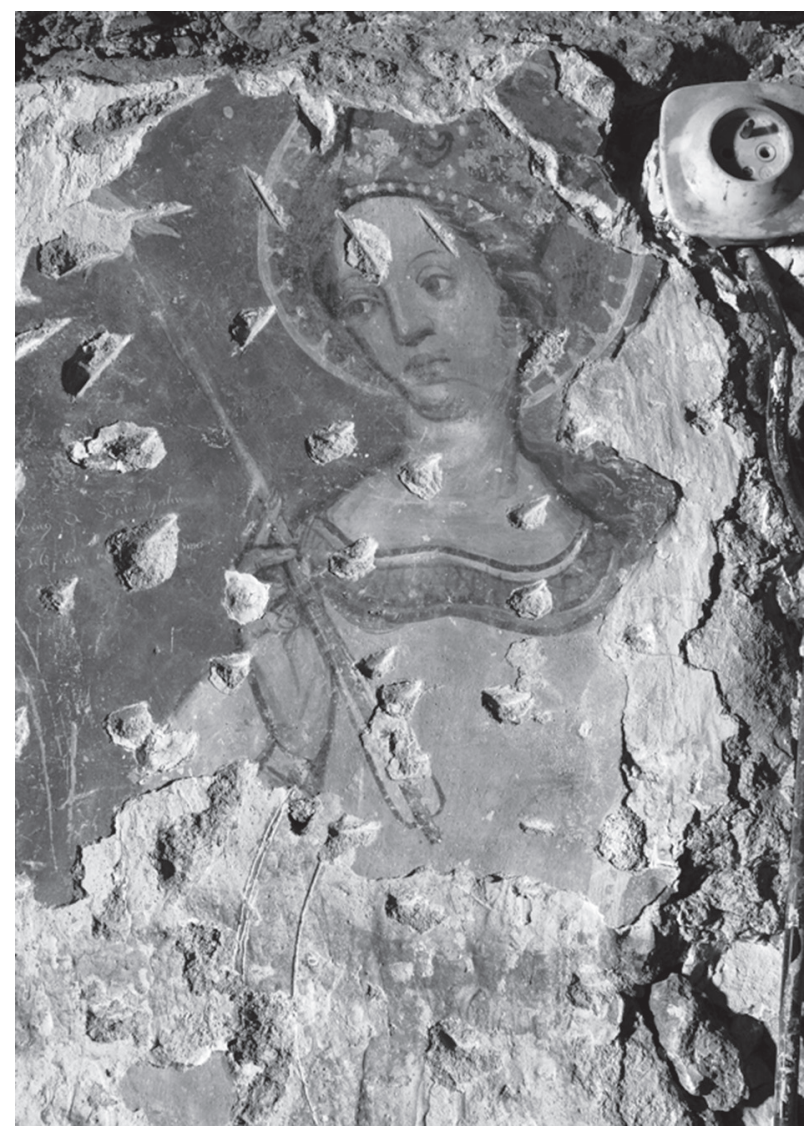

Abb. 8. Torna, Pfarrkirche, die Hl. Ursula an der Ostwand des Chores, vor der Restaurierung

am Fuß der Kirche zu Torna (Abb. 6). ${ }^{5}$ Der Kelch wird heute im Ungarischen Nationalmuseum in Budapest bewahrt. Paul Özdögei Besenyő hatte zuvor, im Jahr 1396, mit König Sigismund an der großen Schlacht von Nikopol (heute Bulgarien) gegen die Türken teilgenommen.

Die Fresken im Chor der Pfarrkirche Torna (Abb. 7) wurden 2007-2014 vom hervorragenden Restaurator Peter Gomboš aus Kaschau (Košice, Slowakei) entdeckt. ${ }^{6}$ Er fand zwei Farbschichten. Die erste Phase der malerischen Dekoration vom Anfang des 14. Jahrhunderts stellen die Weihekreuze dar. Aus der zweiten Schicht ist eine wunderbare Reihe von gotischen Frauengestalten bekannt, über denen die Reste zweier biblischer Zyklen zu sehen sind, welche die Passion und die Kindheit Christi abbilden. Die Untersuchungen ergaben, dass der ganze Chor, die Seitenwände und auch das Gewölbe am Anfang des 15. Jahrhunderts mit figuraler Malerei dekoriert wurden. Diese Fresken zeigen ein sehr hohes künstlerisches Niveau des Schönen Stils.

An der Ostwand des polygonalen Chors, oberhalb des gemalten Vorhangs, sehen wir acht dekorative,

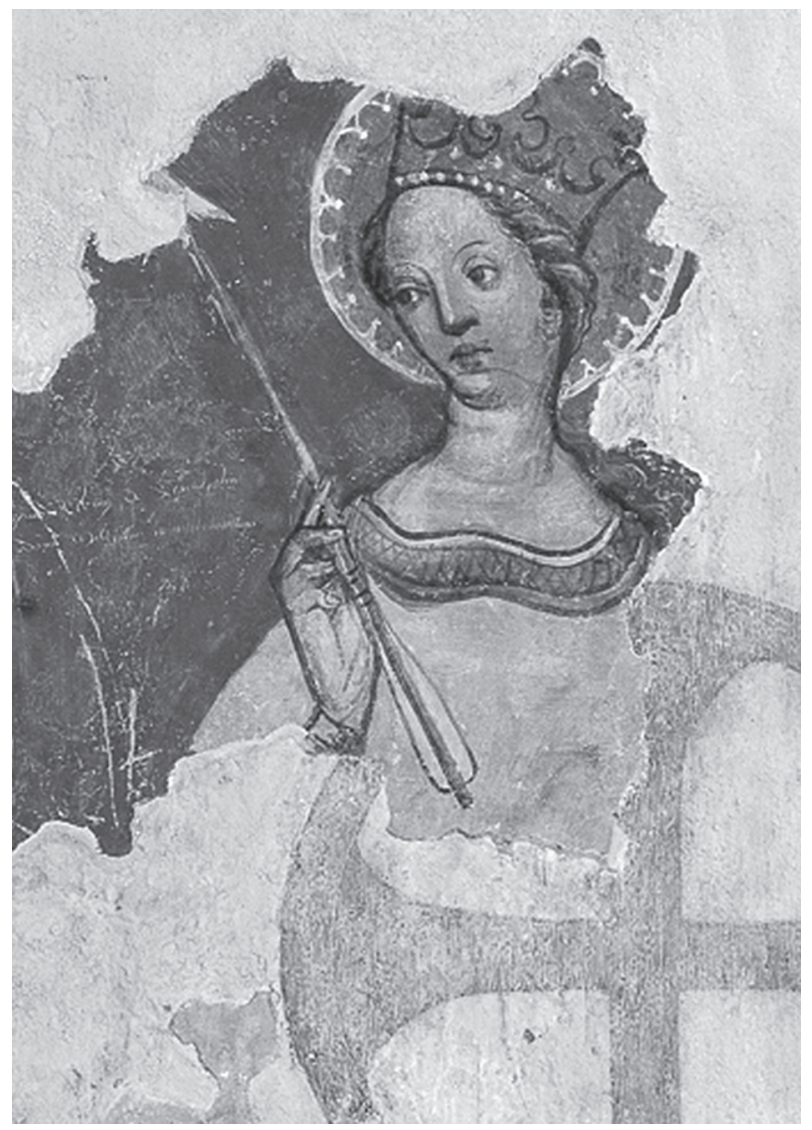

Abb. 9. Torna, Pfarrkirche, die Hl. Ursula an der Ostwand des Chores, nach der Restaurierung

junge heilige Frauen, die in Dreiviertel-Lebensgröße in den gemalten Nischen stehen. Ihre Zahl betrug ursprünglich neun oder noch mehr, aber sie sind nicht mehr erhalten. Die Figur an der Südostwand wurde im 19. Jahrhundert zerstört, als der Grabstein von Johann Tornai vom Boden gehoben und in die Wand eingemauert wurde. Die meisten Frauen sind mit Krone dargestellt. Ihre Attribute sind nicht immer gut sichtbar, so kann man nicht alle heiligen Frauen eindeutig bestimmen. Die zarte Frau in der Mitte des Chors, an der Ostwand trägt ein langes, weißes Kleid mit breitem Ausschnitt und hält einen Pfeil in ihrer rechten Hand. Sie stellt die Hl. Ursula dar (Abb. 8-9). Sie, die Tochter des Königs von Britannien, hatte im 5. Jahrhundert in Köln den Märtyrertod von den Hunnen erlitten. Der untere Teil der Figur ist zerstört, so kann man das Weihekreuz der früheren Freskenschicht sehen. Links daneben sieht man die Hl. Dorothea mit Rosenkranz am Kopf und Blumenkorb in der Hand (Abb. 10). Sie war eine vornehme Frau aus Kappadokien und wurde im 4. Jahrhundert während der Christenverfolgung des Kaisers Diokletian ermordet. Für ihre Kopfreliquie in Breslau (Wrocław, Polen) ließ König Sigismund 


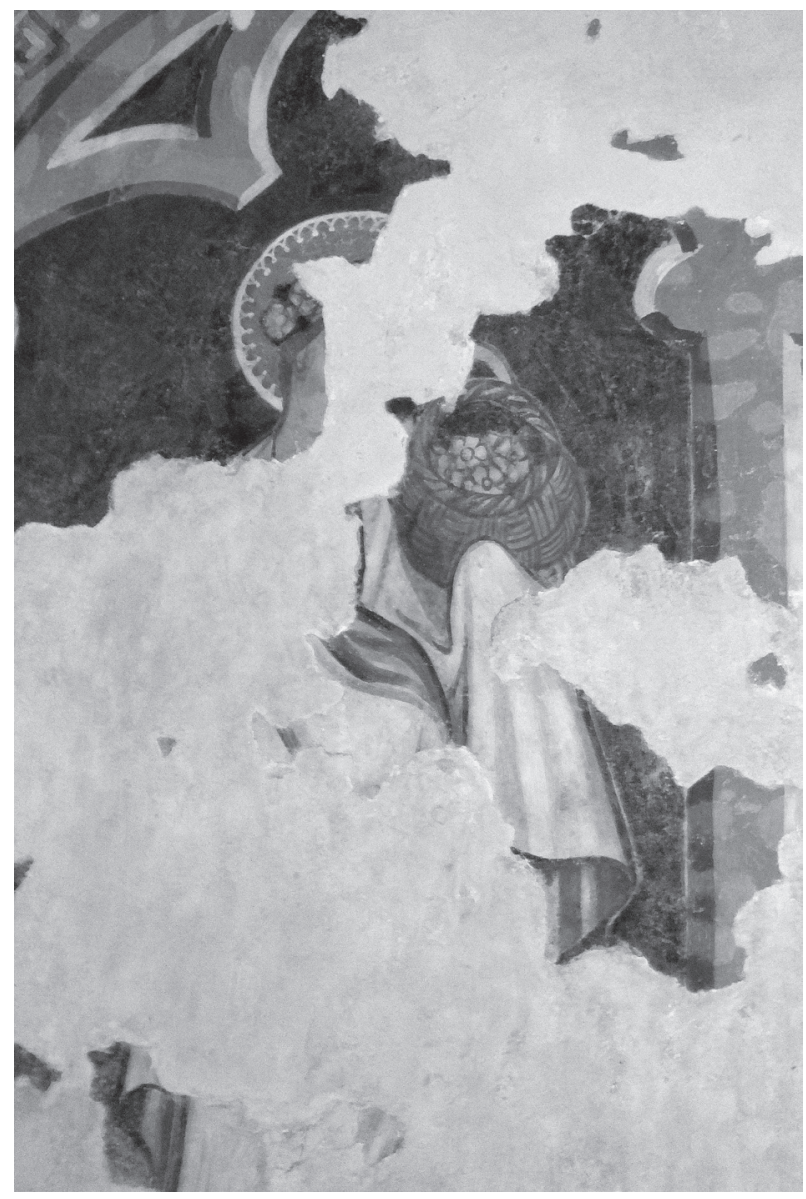

Abb. 10. Torna, Pfarrkirche, die Hl. Dorothea an der Ostwand des Chores, nach der Restaurierung

um 1430 eine wunderbare vergoldete Herme anfertigen. ${ }^{7}$ Die an der Nordostwand dargestellte heilige Frau ist vielleicht die $\mathrm{Hl}$. Christina, die Begleiterin der $\mathrm{Hl}$. Ursula, die von einem Pfeil am Herzen getroffen wurde (Abb. 11). Daneben an der Nordostwand könnte die im einfachen grauen Mantel bekleidete heilige Frau die Hl. Elisabeth von Ungarn (1207-1231) sein, die Schwester des Königs Béla IV., die eine der ersten Anhänger des Hl. Franz von Assisi war (Abb. 12). Als Witwe wurde sie Mitglied des für die Laien gegründeten so genannten „Dritten Ordens des Hl. Franziskus". Ihre Verehrung verbreitete sich nach ihrer Heiligsprechung 1235 in ganz Europa. Auch die Tochter von Sigismund erhielt den Namen Elisabeth. Rechts von der Hl. Ursula hält die gekrönte heilige Frau einen Palmenzweig in ihrer linken Hand - das allgemeine Symbol des Martyriums - und eine Platte in der rechten Hand, wo die Darstellung nicht mehr sichtbar ist (Abb. 13). Vielleicht war da ein Lamm dargestellt, so wurde in ihr die $\mathrm{Hl}$. Agnes verehrt. Rechts von ihr an der Südostwand sehen wir die am besten erhaltene heilige Frauengestalt. Sie ist die Hl. Margareta von

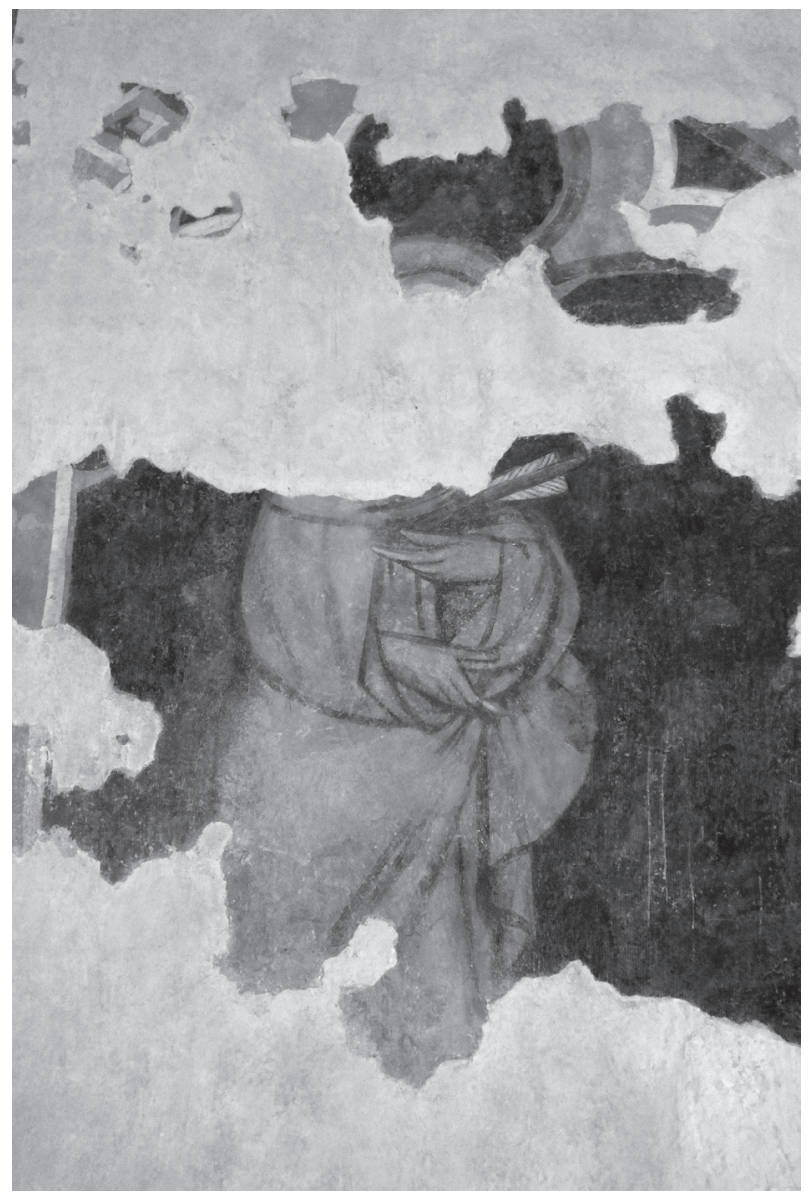

Abb. 11. Torna, Pfarrkirche, die Hl. Christina an der Nordostwand des Chores, nach der Restaurierung

Antiochien (Abb. 14-15). Sie hält den Drachen in ihrer rechten Hand und das Kreuz in der linken Hand. Wie bekannt, besiegte sie im 3. Jahrhundert den Drachen mit dem Kreuz. Ihre Kopfreliquie hatte der Ungarkönig Andreas II. (1205-1235) während des von ihm geführten Kreuzzuges 1217 von Antiochien nach Ungarn gebracht, nach Esztergom, wo seine Residenz war. Seit 1217 wurde die Hl. Margareta von Antiochien als Patrona Hungariae verehrt. Die Tochter von König Béla IV., die während des Mongolensturms von 1241 geboren wurde, hatte ihren Namen von der Hl. Margareta von Antiochien bekommen. Rechts von der Hl. Margareta von Antiochien, neben der Sitznische für die Priester, steht das Bild einer Königstochter, die einen Hermelinmantel trägt (Abb. 16). Ihre Attribute sind nicht mehr sichtbar. Sie könnte die Hl. Barbara sein, die nach der zweiten Ehe des Königs Sigismund mit Barbara von Cille (1405) besonders verehrt wurde.

In diese Reihe der heiligen Frauen gehörten noch zwei weitere Gestalten, die nicht mehr zu bestimmen sind. Eine sollte die Hl. Katharina von Alexandrien darstellen, die zu den vier Virgines Capitales gehörte, die 


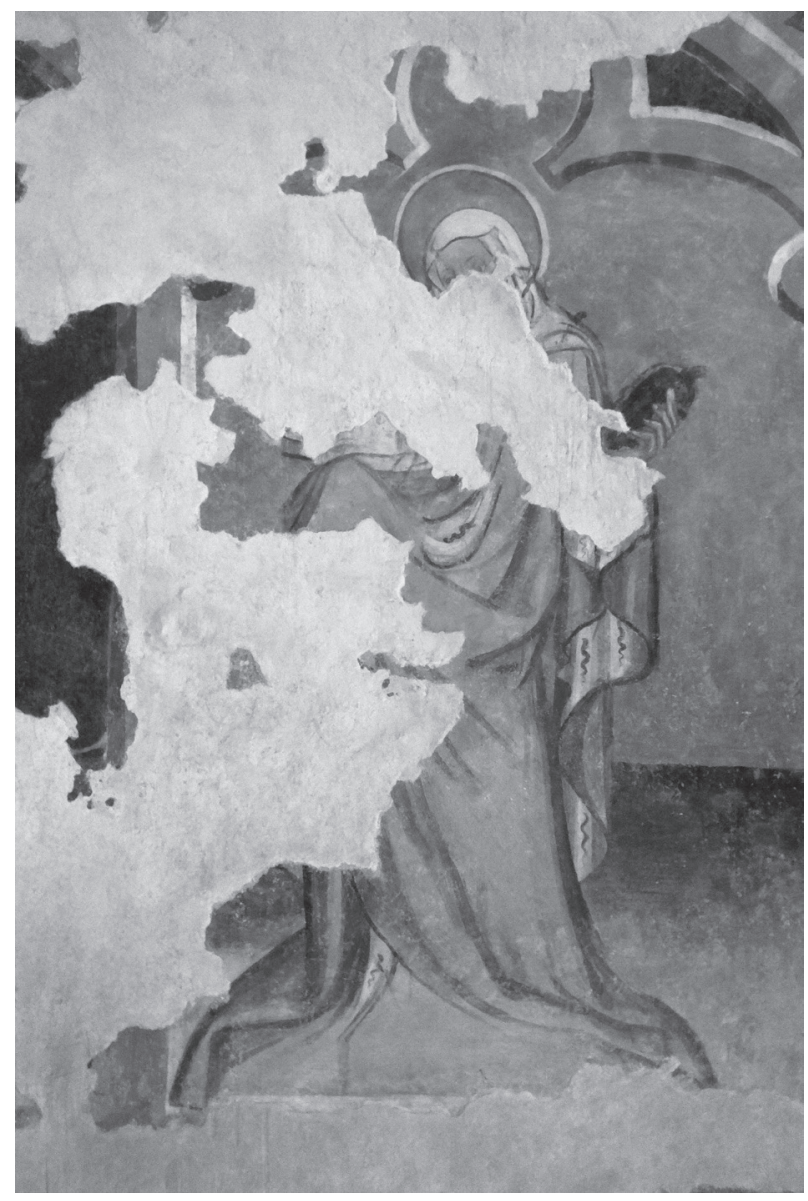

Abb. 12. Torna, Pfarrkirche, die Hl. Elisabeth von Ungarn an der Nordostwand des Chores, nach der Restaurierung

im Christentum bereits von dem 14. Jahrhundert an gemeinsam sehr verehrt wurden: die Hl. Margareta von Antiochien, die Hl. Katharina von Alexandrien, die Hl. Barbara und die Hl. Dorothea. Vor dem 15. Jahrhundert hatten sie jedoch in der Ausschmückung des Kirchenchores keine wichtige Rolle gespielt. Im 14. Jahrhundert wurden sie zumeist an der Fensterlaibung dargestellt. Damals waren die Hauptfiguren des Chores meistens die Apostelgestalten. Sie sind die Säulen der Kirche, sie vermitteln die Lehre von Christus.

In Torna ist es merkwürdig, dass die Reihe der heiligen Frauen im Chor die Aposteln fast in gleichem Maßstab ersetzte. Auch diese Tatsache beweist, dass die Fresken von Torna zum Geist der Internationalen Gotik um 1400 gehören, die von einer besonderen Verehrung der Frauen - besonders der Muttergottes charakterisiert war. Es ist wohlbekannt, dass sich die Liturgie der römischen Kirche im Kanon-Gebet von Anfang an an die heiligen Märtyrerinnen - Felicitas, Perpetua, Agatha, Lucia, Agnes, Cecilia, Anastasia usw. erinnert. Ihre Darstellung bekam aber nur um 1400 eine Priorität. So zum Beispiel in Südwestungarn, in der

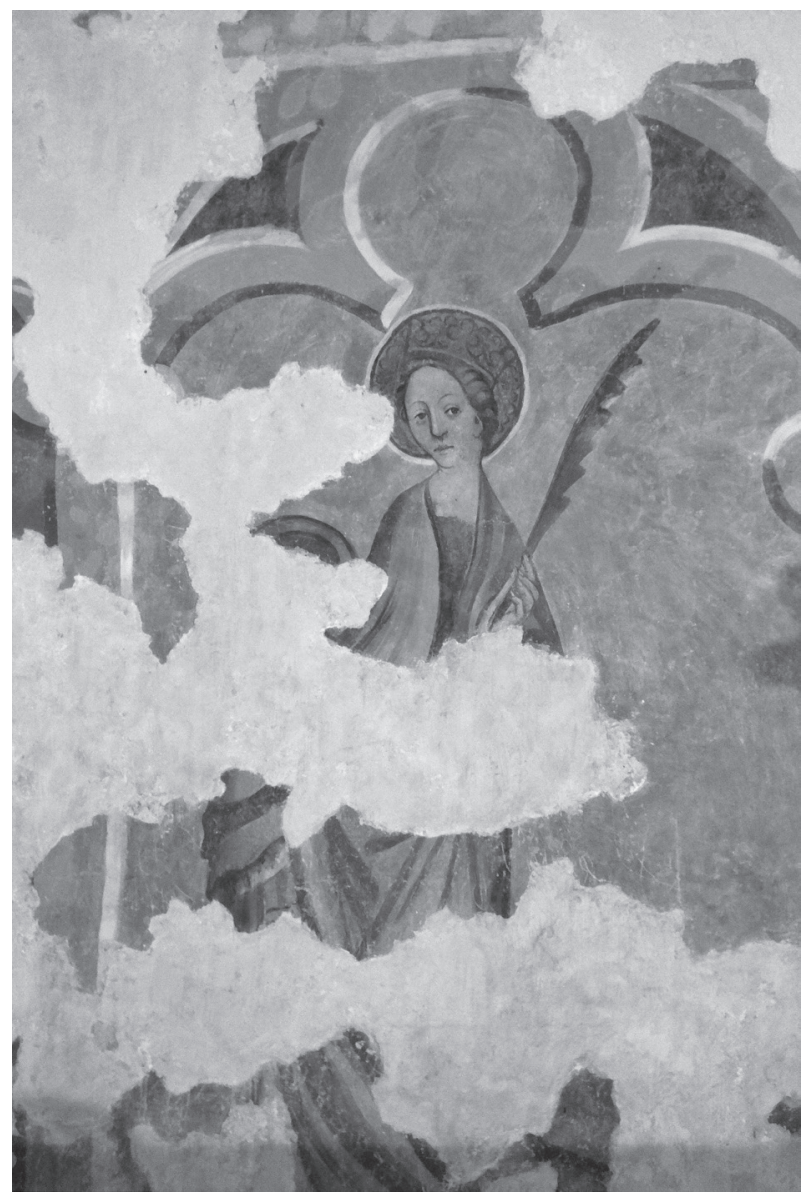

Abb. 13. Torna, Pfarrkirche, eine heilige Frau an der Ostwand des Chores, nach der Restaurierung

Kirche von Mártonhely (Martjanci, heute Slowenien) malte Johannes Aquila im Jahr 1392 heilige Frauen an die Ostwand des Chores ${ }^{8}$ an einer ähnlichen Stelle, wie in Torna (Abb. 17). Da sehen wir die Hl. Elisabeth mit den Rosen, die Hl. Helena mit dem von ihr aufgefundenen Kreuz, die Hl. Barbara mit dem Turm, wo sie von ihrem Vater eingesperrt wurde, die Hl. Margareta von Antiochien mit dem Drachen, dem Symbol des Satans, den sie mit dem Kreuz Christi besiegt hat, die Hl. Apollonia mit der Zange, dem Gerät ihres Martyriums, und die Hl. Hedwig, Herzogin von Schlesien, die Tante der Hl. Elisabeth von Ungarn mit dem Kirchenmodell, an ihre viele Kirchengründungen erinnernd.

Es gibt noch viele andere Beispiele für die Verbreitung der Darstellungen der heiligen Frauen in der Ausschmückung der Kirche um 1400. Wir nehmen an, dass die Kirche von Torna ihr neues Patrozinium zur Himmelfahrt Mariae damals bekommen hatte und die gotische Freskendekoration daher nach 1409 anzusetzen ist.

Oberhalb der Reihe der heiligen Frauen befinden sich die Szenen aus dem Leben Christi in drei Strei- 


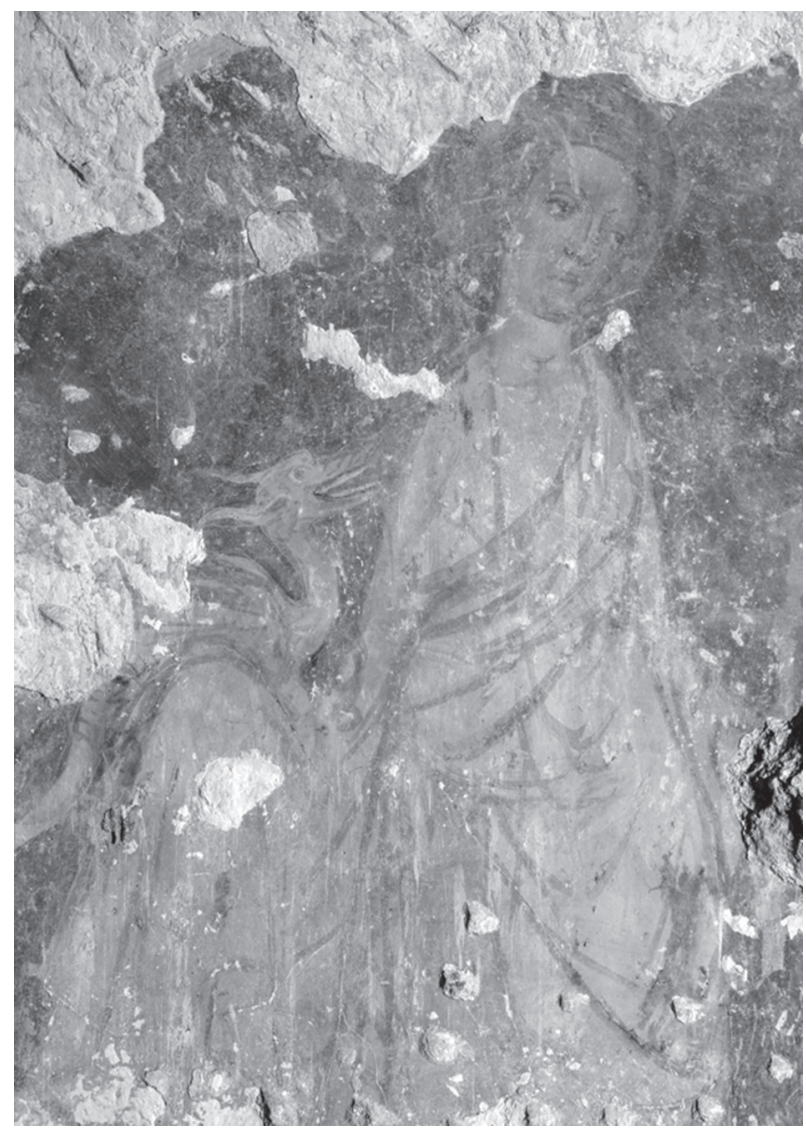

Abb. 14. Torna, Pfarrkirche, die Hl. Margareta von Antiochien an der Südostwand des Chores, vor der Restaurierung

fen. Die Geschichte Christi begann einst an der Nordwand, da wurden aber die Fresken zerstört. Sie sind nur an der Nordost- und Ostwand erhalten geblieben. Im obersten Streifen der Nordostwand ist das Fragment der Geburt Christi sichtbar (Abb. 18). Die Jungfrau Maria kniet betend unter dem Strohdach des Stalls vor ihrem neugeborenen Sohn, aber das Kind ist leider nicht mehr sichtbar. Auch von Marias Gestalt sieht man nur das verklärte Gesicht und die betenden Hände mit expressiv verlängerten Fingern: Sie ist von Gottes Gnade tief gerührt. Das baufällige Strohdach vor dem blauen Himmel ist rein malerisch dargestellt.

Im zweiten Streifen sind zwei Szenen aus der Passion Christi erhalten: die Ölbergszene und die Gefangennahme Christi (Abb. 19). Am ersten Bild betet Jesu kniend zwischen hohen Felsen mit tiefem Schmerz vor seinem grausamen Leiden und Tod (Abb. 20). Die zwei liebsten Jünger, Petrus und Johannes, die er gebeten hat mit ihm zu beten, sind eingeschlafen. Ihre Figuren sind durch Felsen von Christus getrennt, um anzudeuten, dass sie fern von Christi Gedanken sind. Das Bild

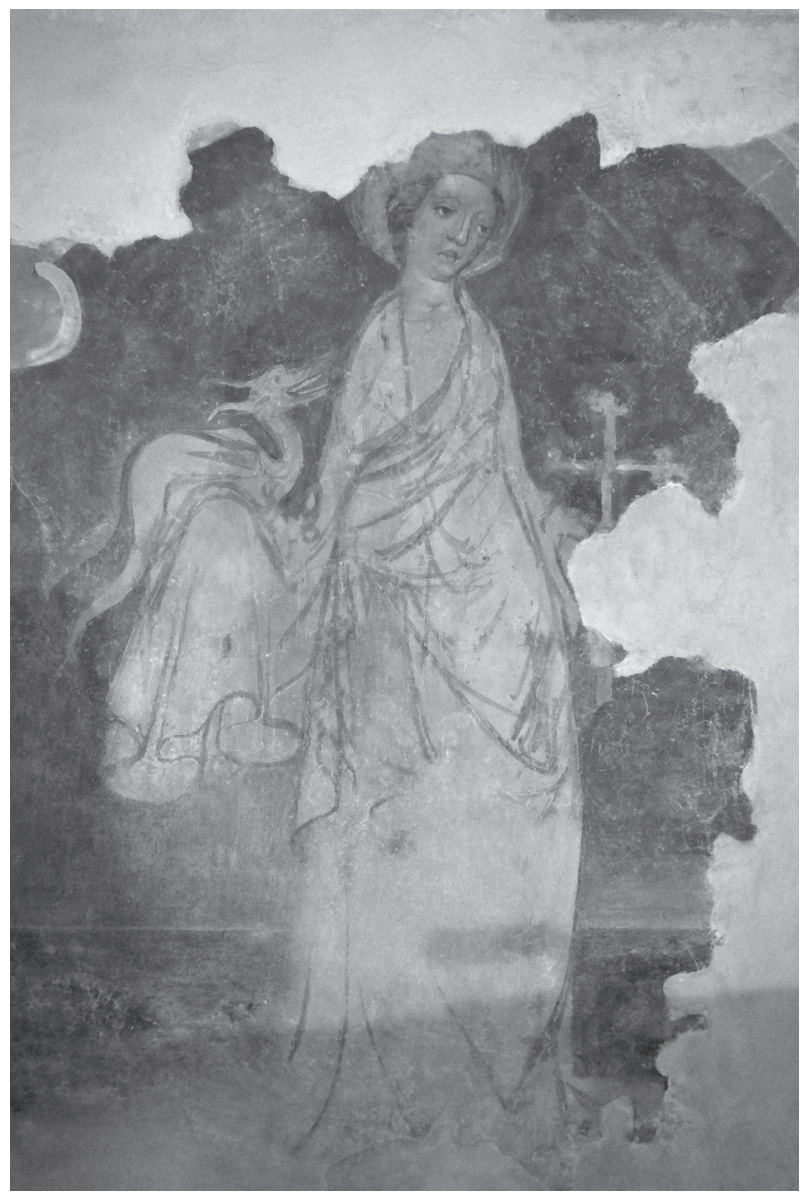

Abb. 15. Torna, Pfarrkirche, die Hl. Margareta von Antiochien an der Südostwand des Chores, nach der Restaurierung

voll mit tiefen Emotionen ist streng komponiert und schön malerisch verfertigt. Hier sehen wir, dass der begabte Künstler die inneren Gefühle der Figuren nicht nur mit den Gesichtern und mit den Händen zeigt, die hier große und sehr künstlerische Varietät haben, sondern mit ihren ganzen Körpern, durch ihre künstlerisch schön dargestellten verschiedenen Haltungen.

Die vielfigurige breite Szene der Gefangennahme Christi an der Ostwand (Abb. 21) ist durch ein Rundfenster von oben beleuchtet, dessen Laibung mit dekorativen Mustern künstlerisch bemalt ist. Im Zentrum ist der Kuss von Judas dargestellt. Er kommt von links, umarmt Jesus, die Gesichter berühren sich im Dreiviertel-Profil. Jesus schaut Judas mit suggestivem, fragend liebevollem Blick an. Inzwischen heilt er mit seiner rechten Hand das Ohr des Dieners vom Hohepriester, der vor ihm kniet. Dahinter steht der Apostel Petrus, der eben sein Schwert in die Scheide zurücksetzt. Die Soldaten und die Leute des Hohepriesters diskutieren über Jesu. Besonders ausdrucksvoll sind die Hände dargestellt. Die linke Hand von Judas liegt 


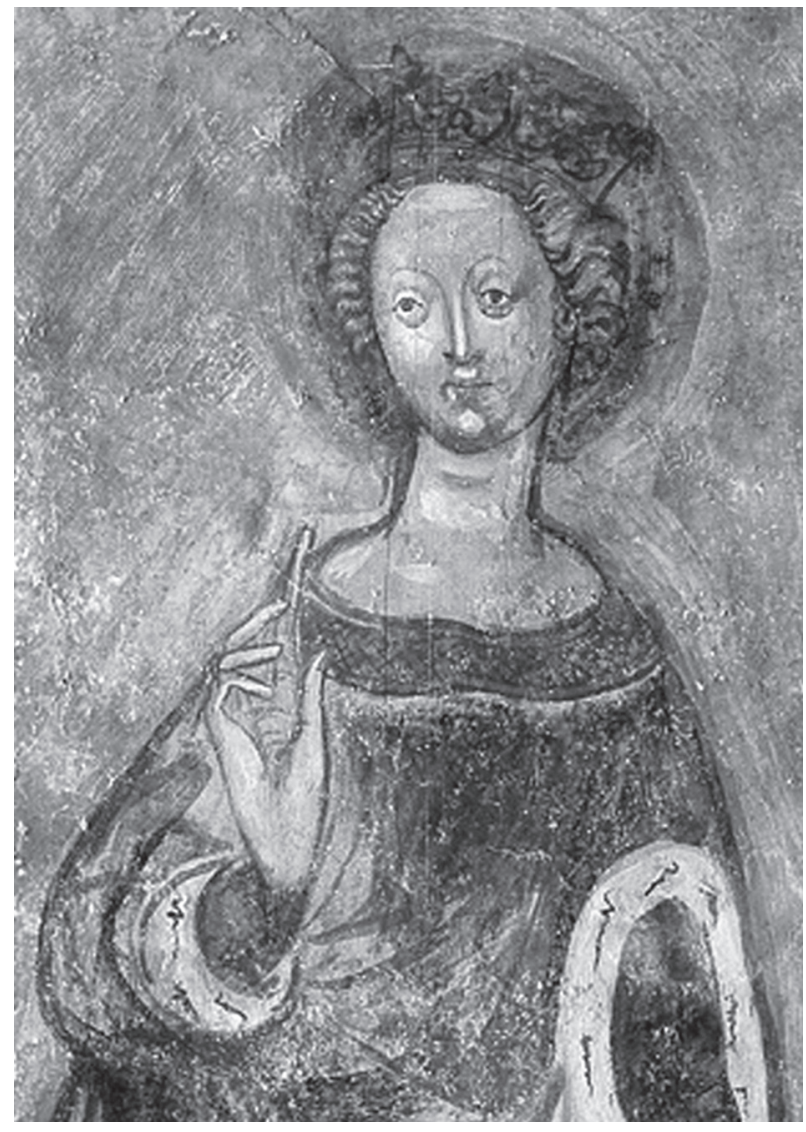

Abb. 16. Torna, Pfarrkirche, eine heilige Frau an der Südwand des Chores, vor der Restaurierung

an der Brust von Jesus. Die schöne, ausdrucksvolle Darstellung dieser Hand charakterisiert - neben dem Gesicht - die Seele von Judas mit hohem künstlerischem Talent. Er möchte sich freundlich und liebevoll zeigen, aber er ist voll von Angst. .

An der Ostwand unter der Gefangennahme Jesu ist die zweite Szene sehr stark zerstört. Man sieht nur die Köpfe und die Heiligenscheine der aufwärts schauenden sechs-sechs Männer. Sie waren die Apostel von der Darstellung der Himmelfahrt Christi. Auch diese kleinen, künstlerischen Darstellungsfragmente beweisen das hohe Talent des Künstlers. Die zentrale Positionierung des Bildes verdient besondere Aufmerksamkeit. Sie zeigt, dass die malerische Dekoration des Chors ein sehr bewusstes theologisches Programm hatte. Es ist würdig, dass in der zur Ehre von Mariä Himmelfahrt geweihten Kirche die Himmelfahrt Christi an der Hauptwand Platz bekommen hat. Die Darstellung der von Engeln in den Himmel aufgehobenen Maria war wahrscheinlich am Altarretabel vor der Ostwand sichtbar.

In der Fortsetzung der Bilderreihe des Lebens Jesu öffnen sich drei gotische Fenster an der Süd- und Süd- ostwand der Kirche. Alle drei Fenster haben ihre malerische Dekoration an der Laibung bewahrt (Abb. 7, Abb. 22-24). Die dort dargestellten je fünf Prophetengestalten gehören eng zum theologischen Programm der malerischen Dekoration der Kirche. Die Propheten hatten alle Ereignisse des Lebens Jesu schon viele hundert Jahre früher vorhergesagt. Ihre Prophezeiungen findet man in der Bibel. Sie bezeugen also, dass Jesus der von Gott für Israel versprochene Erlöser ist. Die Propheten waren von Gott gesendete, verklärte Männer, die die Nachricht Gottes vermittelten. Sie sind in Torna in Dreiviertelgestalt dargestellt. Sie halten ein langes weißes Band mit der Inschrift ihres Namens, das leider nicht mehr eindeutig lesbar ist. Das Band rahmte die Gestalten schwungvoll schweifend, an einem Fenster von rechts und am anderen von links. Der Künstler des größten Teils der Propheten war der eminente Hauptmeister, den wir bereits kennengelernt haben. Die schönen, expressiv verklärten, ein wenig verlängerten Gesichter und die körperlosen Gestalten mit dekorativem Faltenwurf sind seine Charakterzüge. Er hatte einen Assistenten, der auch ein begabter Künstler war, aber mit anderem Charakter. Seine Propheten betonen die irdischen Züge, dass die Propheten auch Menschen waren.

Oberhalb des Südostfensters erscheint die Halbfigur des Evangelisten Johannes in einem Tondo (Abb. 25). Er hält einen Kelch in der Hand. Er kündet die wahre Lehre Christi über die Eucharistie während der Hussitenzeit. Über dem benachbarten südlichen Fenster ist Johannes der Täufer dargestellt (Abb. 26). Er war der Vorgänger Christi, der auf Jesus als Messias hinwies, der von Gott gekommen war. Das Bild in Torna zeigt ihn, den letzten Propheten, vor dem blauen Hintergrund in roter Kleidung, die auch ein Hinweis auf seinen Märtyrertod ist. Er hält eine Scheibe mit dem Lamm Gottes in seiner linken Hand fest und weist darauf mit seiner rechten Hand hin. Er betont mit dem verlängerten Zeigefinger und mit dem suggestiven Blick für alle Leute, die dieses Bild anschauen, dass Jesus das Lamm Gottes ist, der in der Eucharistie wahrhaft anwesend ist. Dies war eine wichtige Lehre in der Hussitenzeit. ${ }^{9}$ Wie bekannt, hatte der König (später auch Kaiser) Sigismund - begleitet von mehreren ungarischen Würdenträgern - am Konzil von Konstanz (1414-1418) die Einheit der katholischen Kirche wiederhergestellt. Die betonte Platzierung der Darstellung von Johannes dem Täufer zeigt auch die enge Verbindung mit der berühmten Prämonstratenserabtei Jászó (heute Jasov, Slowakei), die ebenfalls am Fluss Bódva, 20 km nördlich von Torna liegt. 


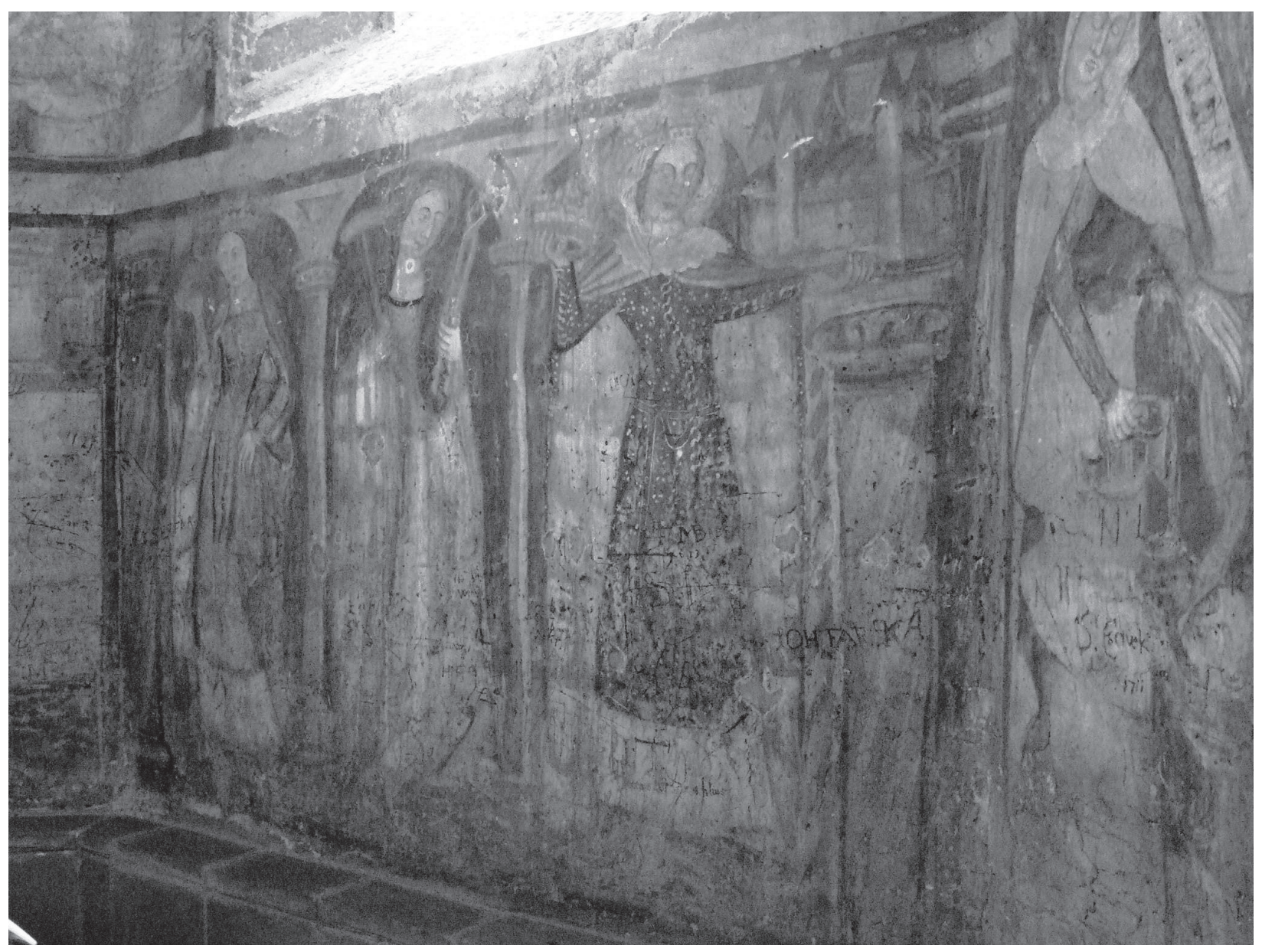

Abb. 17. Mártonhely, Pfarrkirche, heilige Frauen im Chor (Foto: Pál Lóvei)

In der Pfarrkirche von Torna befindet sich an der Südwand des Chores, unter den Fenstern eine Sitznische für den die Liturgie zelebrierenden Priester und für seine Assistenten. Sie besteht aus vier spitzbogigen Nischen, in denen die Wandmalerei je einen lebhaft bewegten, lächelnden Engel darstellt (Abb. 27-30). Sie stehen vor einem grünen Hintergrund und halten den mit roten Rosetten dekorierten weißen Vorhang vor sich. Ihre schönen dekorativen Gestalten mit kurzem, blondem, lockigem Haar sind eben vom Himmel herabgeflogen, wie es die ein wenig noch erhobenen Engelflügel zeigen. Diese Flügel umarmen die Engelsköpfe mit wunderbaren dynamischen Linien. Diese Darstellungen der Engel im Hintergrund der Sitznische, also an einem sekundären Platz in der Dekoration, erlauben uns die Feststellung, dass die Kunst der Internationalen Gotik die Entwicklungen der zeitgenössischen Frührenaissance gekannt und in den eigenen gotischen Stil eingebaut hat.

Die Tornaer Fresken stammen von einem erstklassigen Künstler der Internationalen Gotik, im Geist der Devotio Moderna. Wie es wir vom berühmten Buch Imitatio Christi von Thomas Kempen kennen, hat die
Devotio Moderna die unmittelbare Zuwendung zu Gott gefordert. Da Frauen meistens empfänglicher für Gott und für die übernatürliche Welt sind, erhielten sie in der Zeit um 1400 einen besonderen Respekt.

Wir nehmen an, dass im Chor von Torna außerhalb der erhaltenen Frauengestalten noch mehrere

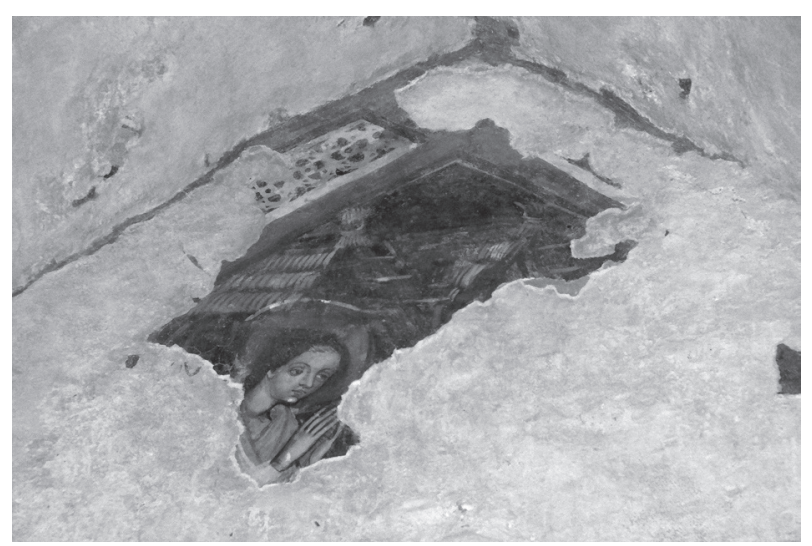

Abb. 18. Torna, Pfarrkirche, die Hl. Maria an der Nordostwand des Chores, Fragment aus der Szene Geburt Christi, nach der Restaurierung 


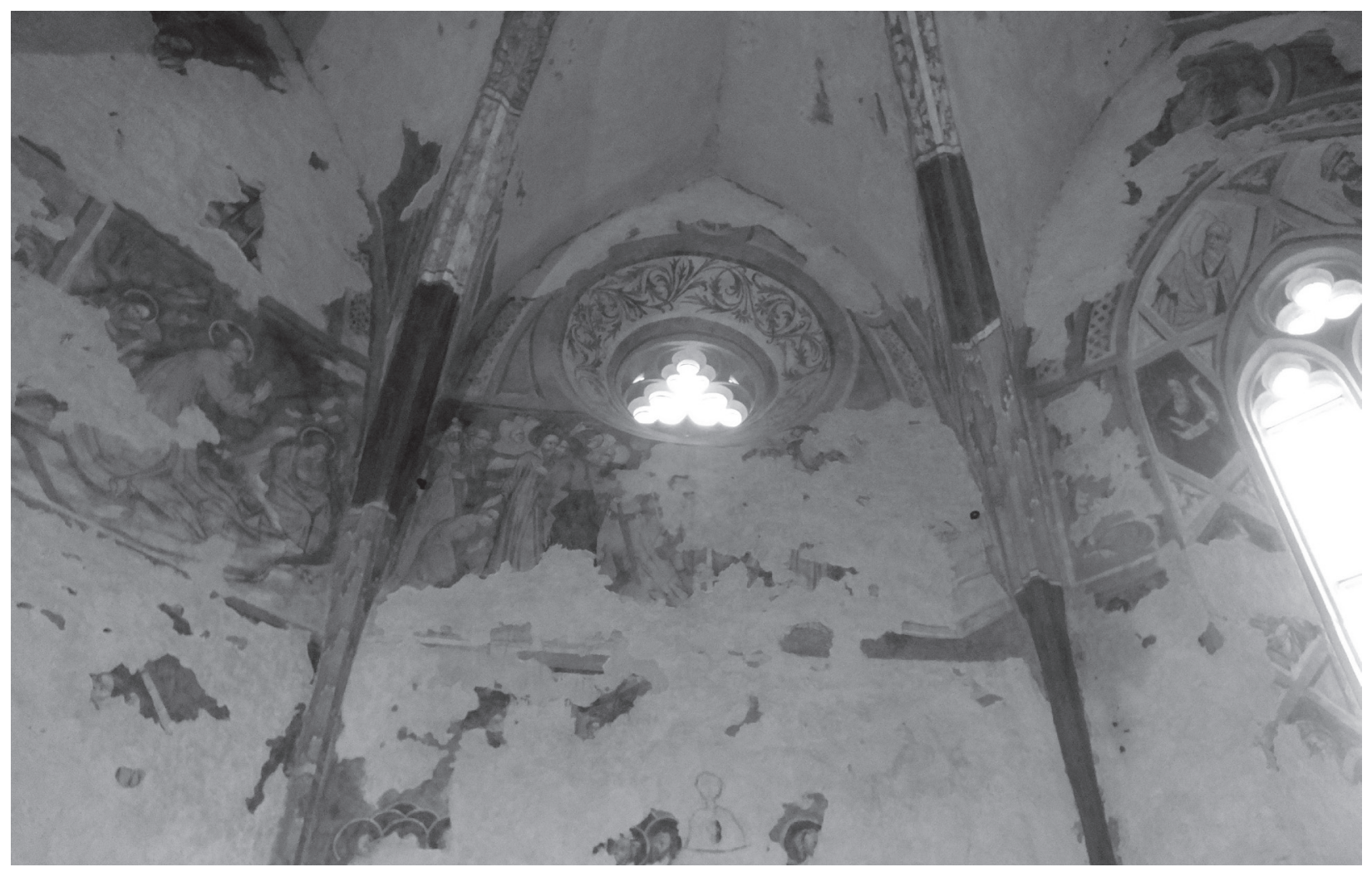

Abb. 19. Torna, Pfarrkirche, die Ostwände des Chores, mit Szenen aus der Passion Christi, nach der Restaurierung

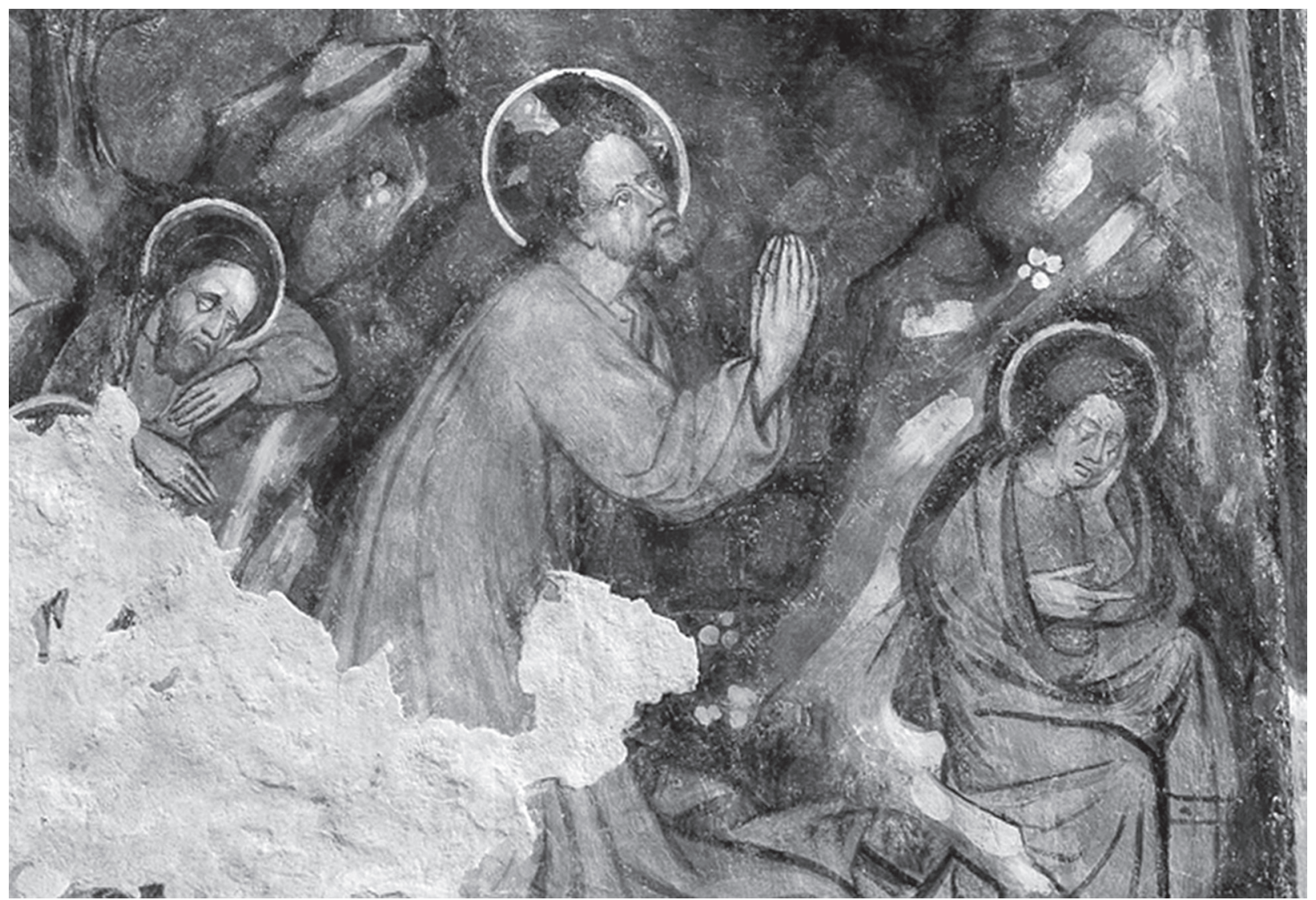

Abb. 20. Torna, Pfarrkirche, die Ölbergszene, nach der Restaurierung 


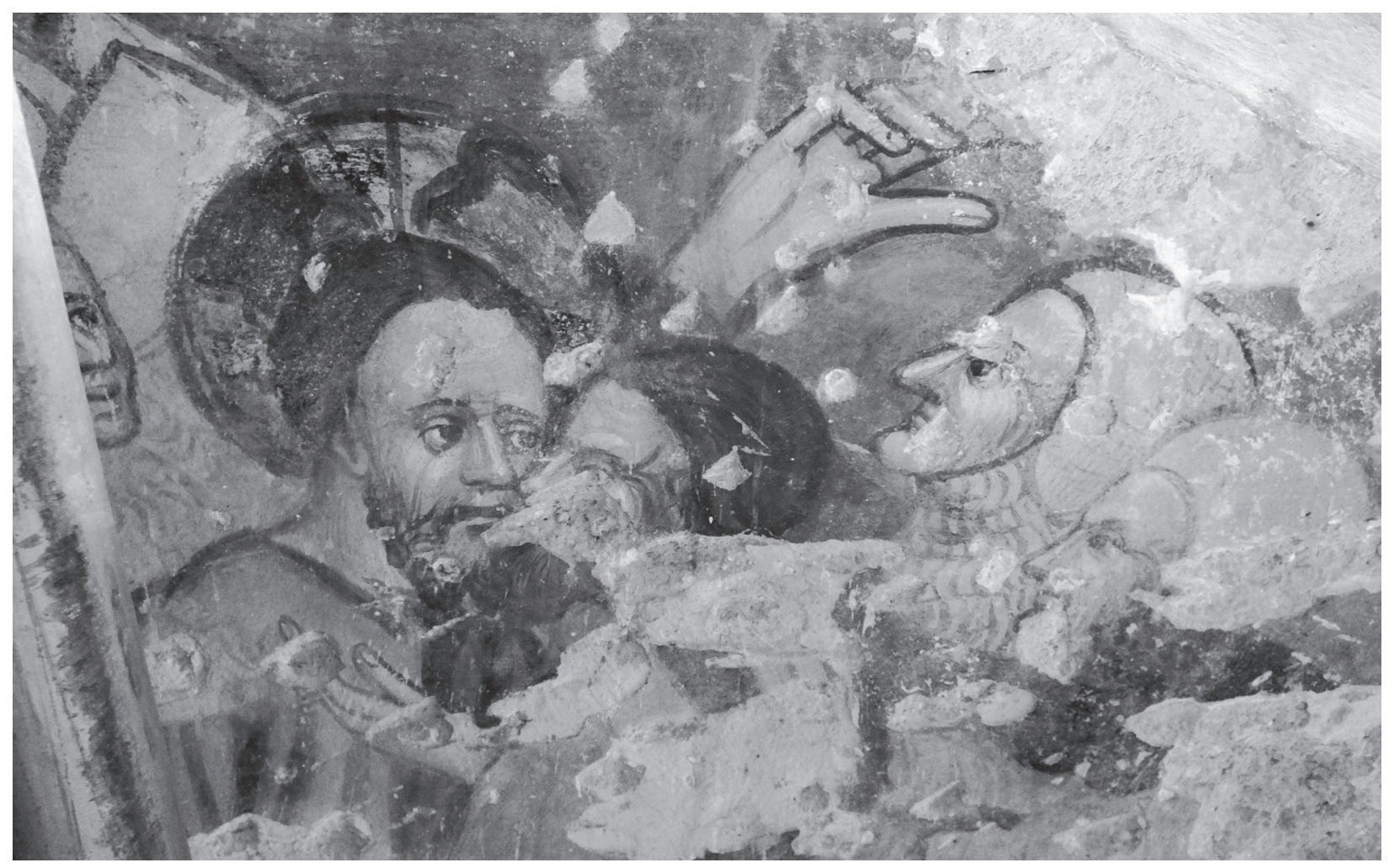

Abb. 21. Torna, Pfarrkirche, Detail der Gefangennahme Christi an der Ostwand des Chores, vor der Restaurierung

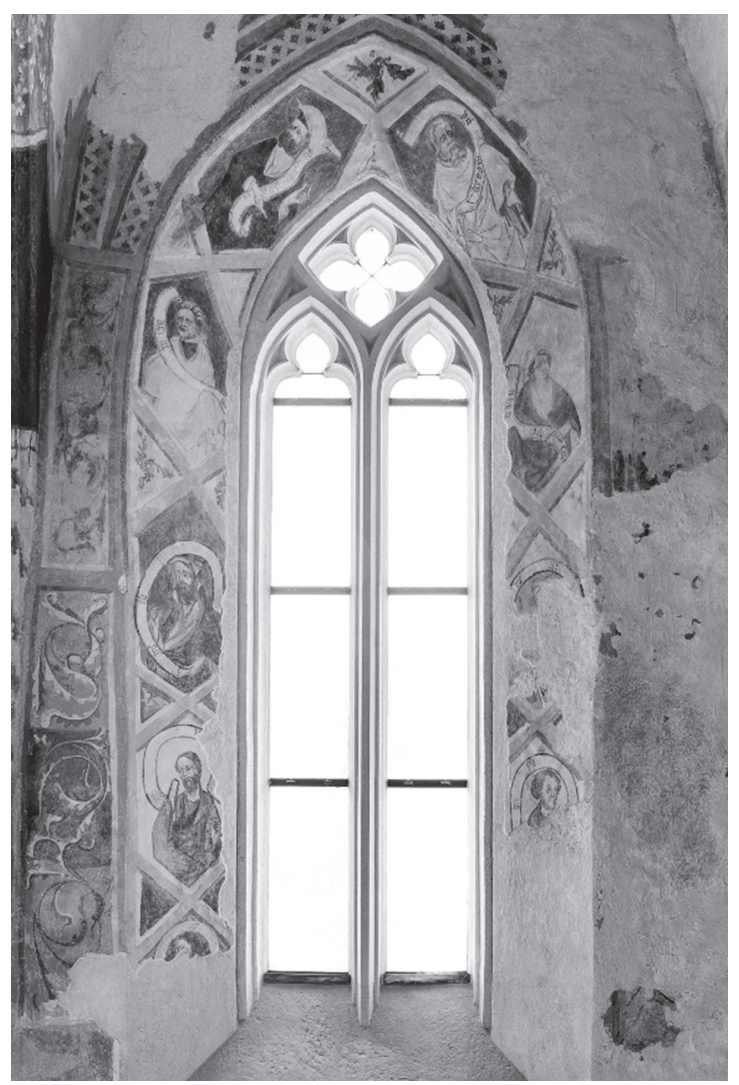

Abb. 22. Torna, Pfarrkirche, Prophetengestalten an der Laibung des südöstlichen Fensters des Chores, nach der Restaurierung

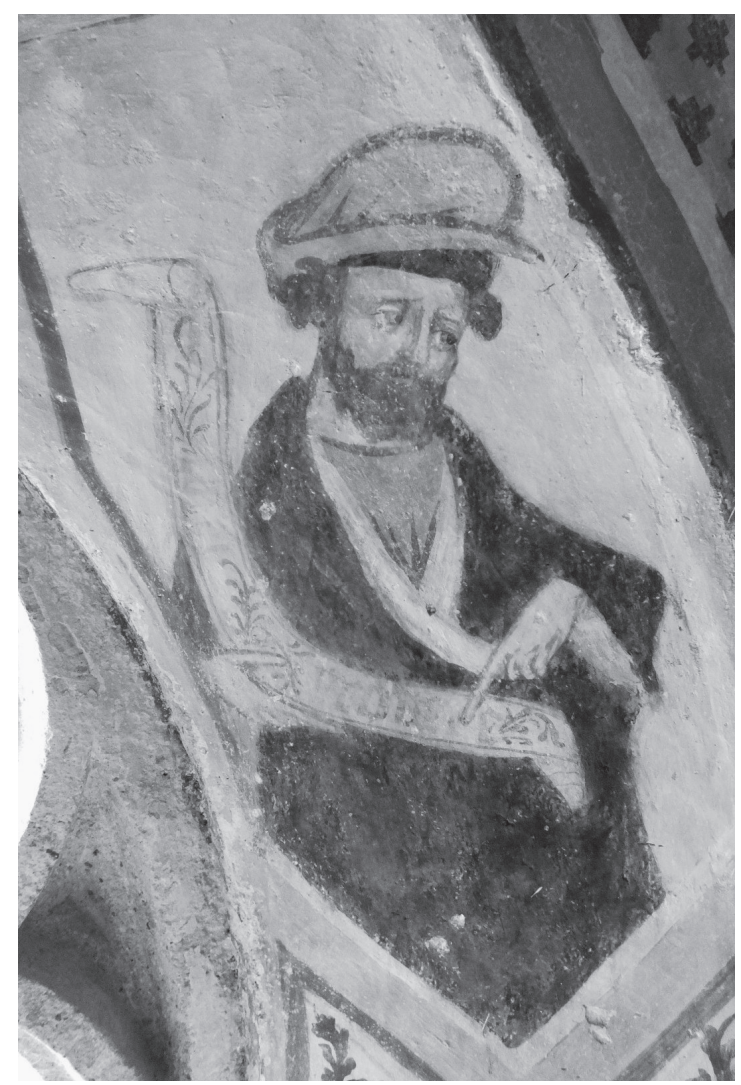

Abb. 23. Torna, Pfarrkirche, Prophetengestalt an der Laibung des südlichen Fensters des Chores, nach der Restaurierung 


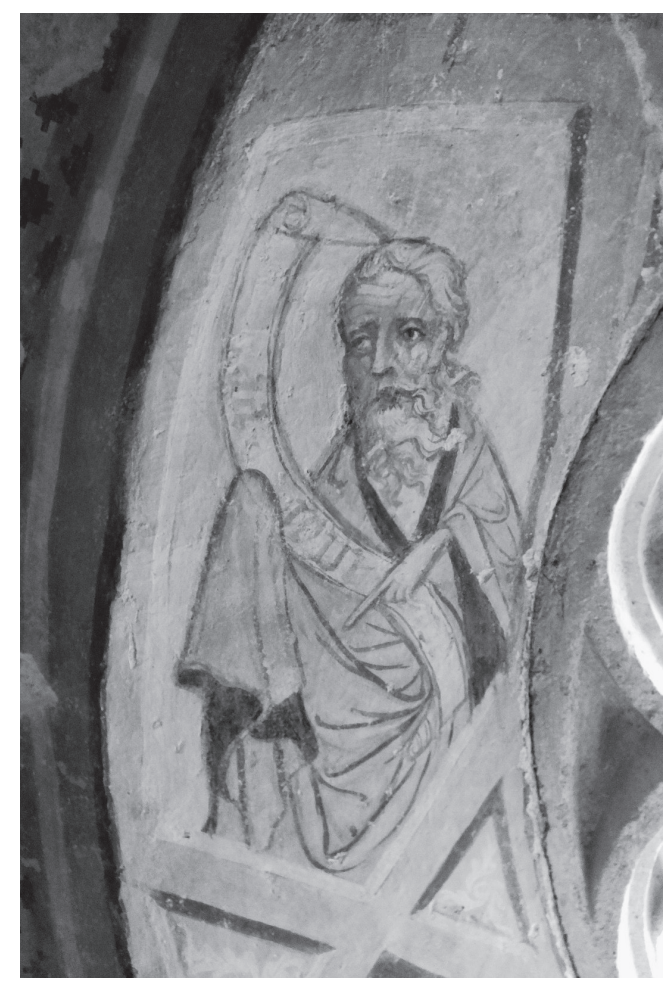

Abb. 24. Torna, Pfarrkirche, Prophetengestalt an der Laibung des südlichen Fensters des Chores, nach der Restaurierung heilige Frauen dargestellt waren, wie die Hl. Helena, Lucia und Hedwig oder noch andere.

Wer war der Maler von Torna? Wo sind seine zeitgenössischen Verwandten? Welchen Platz nehmen die Fresken von Torna in der zeitgenössischen ungarischen und europäischen Kunst ein?

Vom Standpunkt des Stils und des künstlerischen Niveaus können wir mehrere nahe stehende Kunstwerke aus den ersten Jahrzehnten des 15. Jahrhunderts erwähnen. Erstens das Auferstehung ChristiFresko im heutigen Dom von Kaschau/Kassa, der damals eine neue Stadtpfarrkirche am Handelsweg nach Krakau (Polen) war (Abb. 31). ${ }^{10}$ Die Stadt liegt am Fluss Hernád, 40 km östlich von Torna. Zweitens sind zu erwähnen die aus dem Jahr 1427 stammenden Tafelbilder des Kalvarienaltars der königlichen Benediktinerabtei Garamszentbenedek (heute Hronski Benadik, Slowakei), ein Meisterwerk des Hofmalers von König Sigismund, Thomas de Koloswar (Esztergom, Christliches Museum; Abb. 32-33). ${ }^{11}$ Drittens die Skulpturen von dem 1974 ans Licht gekommenen vielfigurigen sog. Budaer Skulpturenfund (Budapest, Historisches Museum Budapest; Abb. 34) $)^{12}$ geben uns ein überzeugendes Beispiel vom künst-

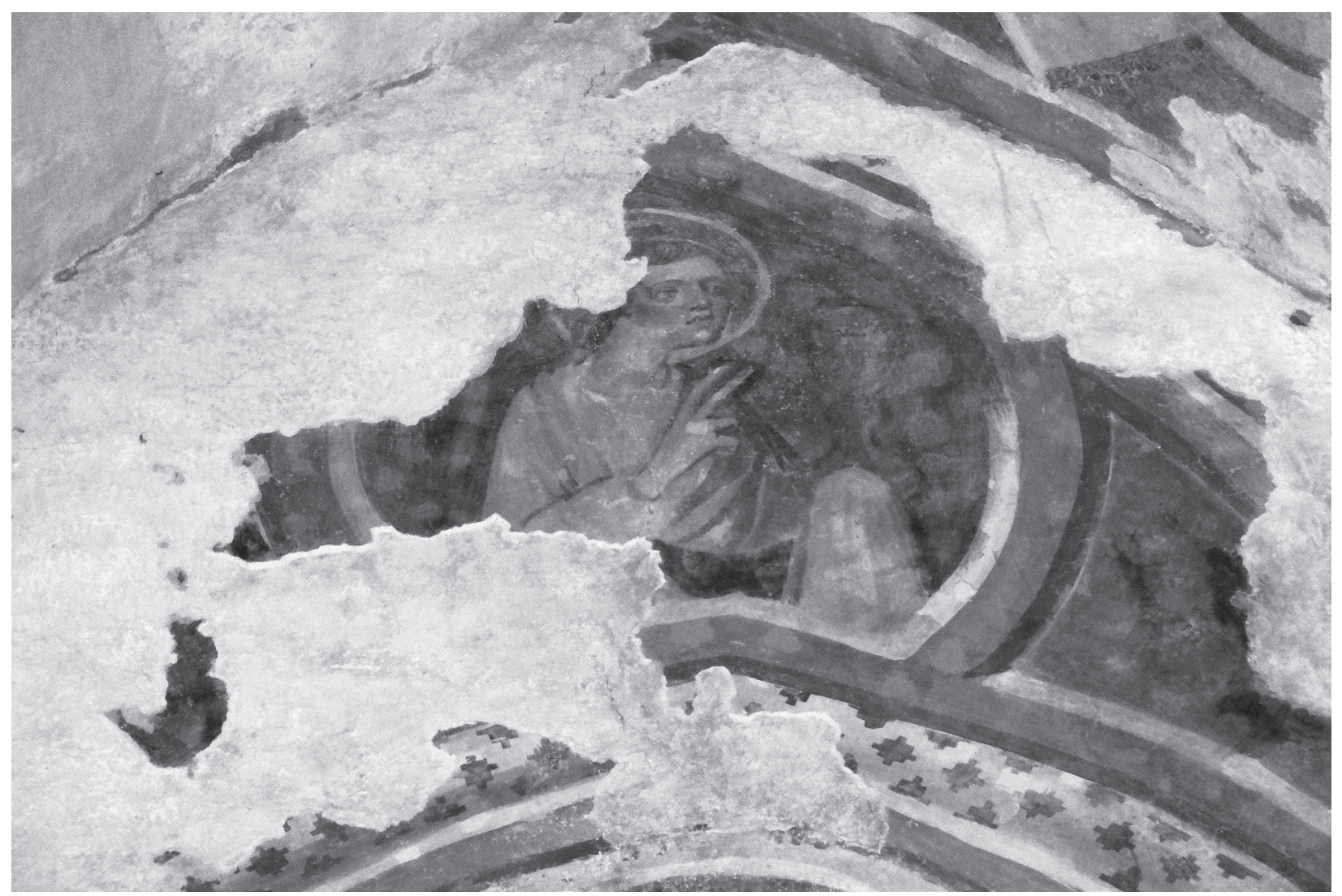

Abb. 25. Torna, Pfarrkirche, Halbfigur des Evangelisten Johannes oberhalb des östlichen Fensters des Chores, nach der Restaurierung 


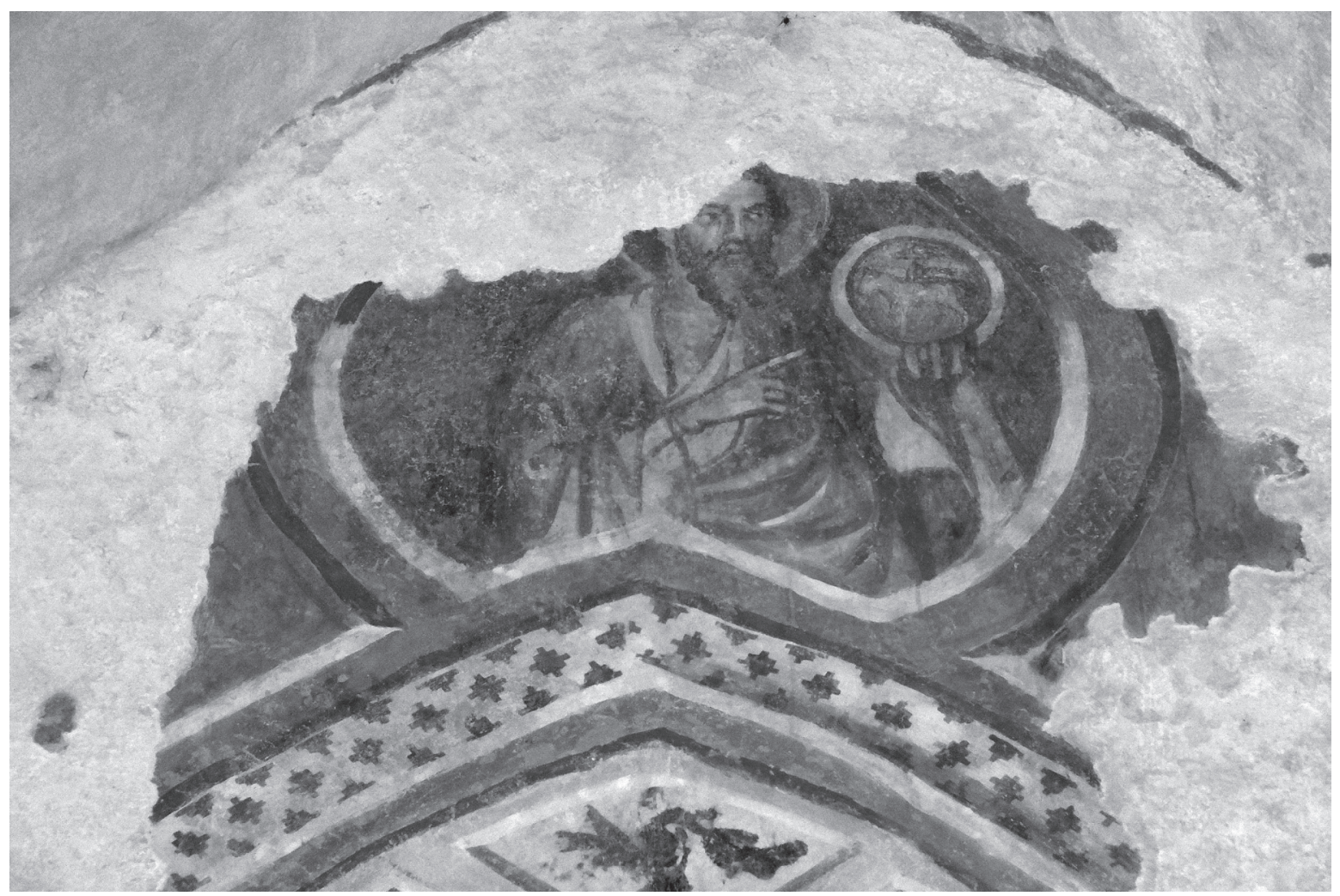

Abb. 26. Torna, Pfarrkirche, Johannes der Täufer oberhalb des südöstlichen Fensters des Chores, nach der Restaurierung

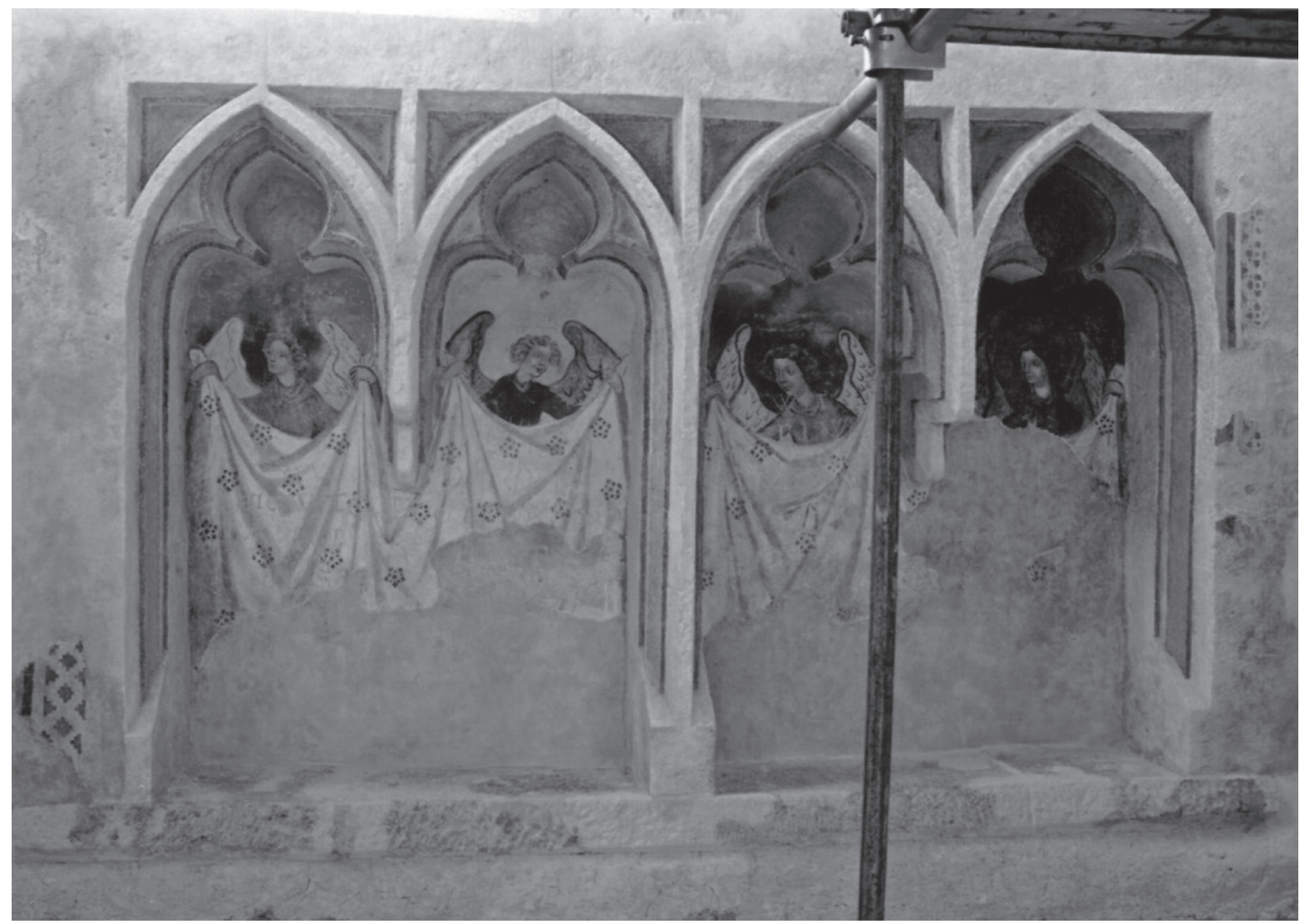

Abb. 27. Torna, Pfarrkirche, lächelnde Engel in der Sitznische der Südwand des Chores, nach der Restaurierung 


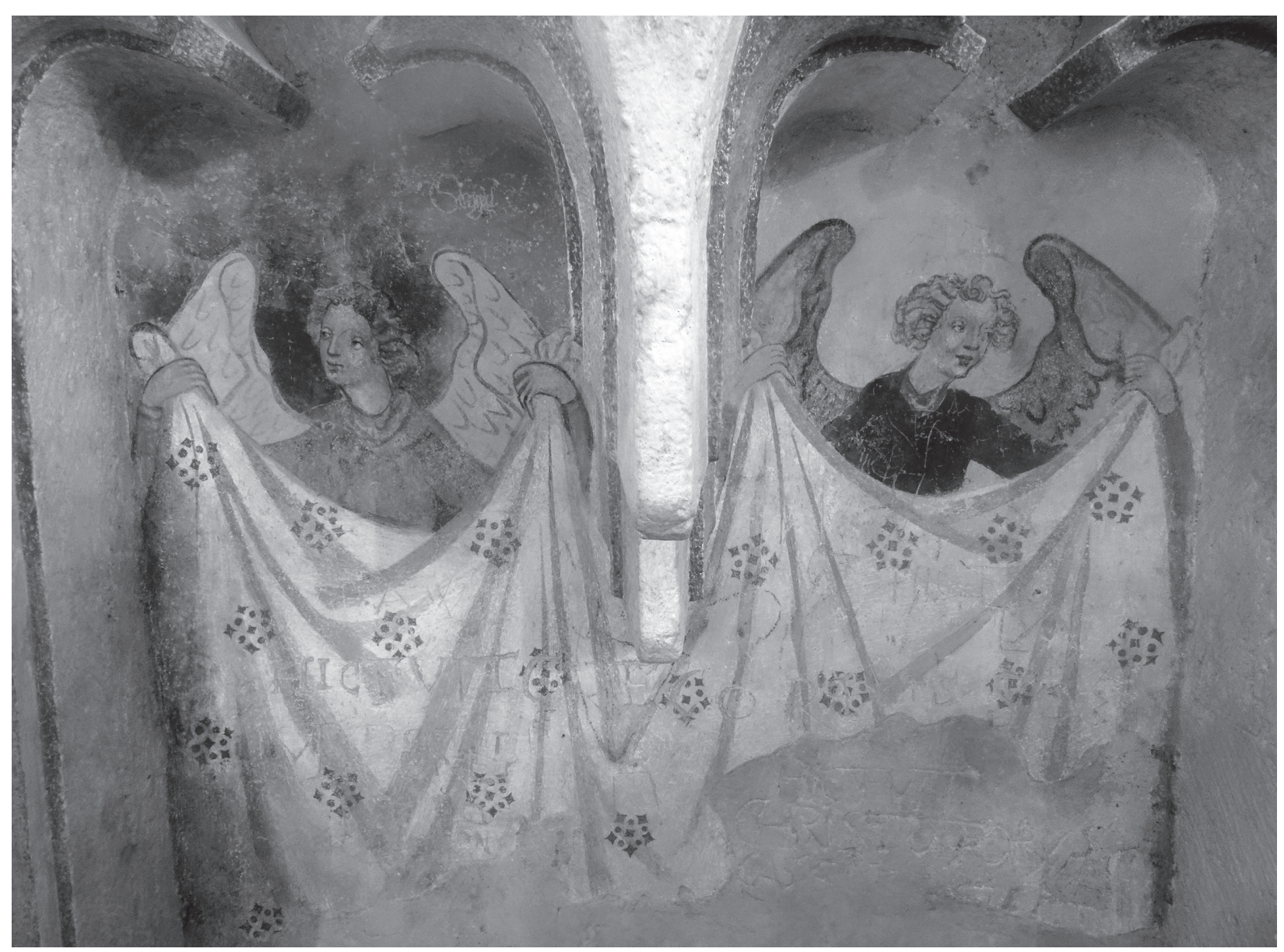

Abb. 28. Zwei Engel in der Sitznische der Südwand des Chores, nach der Restaurierung (Foto: Pál Lővei)

lerischen Niveau der „Budaer Werkstatt“, wie es die tiefgehenden stilistischen Untersuchungen von Prof. Michael Viktor Schwarz festgestellt haben. ${ }^{13}$ Er bestätigte die Existenz der Budaer Werkstatt als eine der wichtigsten Kunstzentren Europas um 1400, die eine wichtige Rolle bei der Entstehung des Schönen Stils spielte. Viertens zeigen auch die zwei wunderbaren Holzfiguren der Hl. Dorothea und der Hl. Katharina von Barka (heute Bôrka, Slowakei) aus der Nähe der Stadt Torna (heute in der Ungarischen Nationalgalerie, Budapest; Abb. 35) $)^{14}$ eine enge Beziehung zu den Fresken von Torna. Die außergewöhnlich verlängerten Proportionen der Figuren und ihre elegante Biegung haben keine stilistischen Parallelen im kontemporären Kunstschaffen Europas. Schließlich sollen wir auch die Aquarelldarstellungen der Triumphzüge des Sigismund und seiner höchsten Würdenträger als Allegorien der sieben Planeten (Bibliothek der Akademie der Wissenschaften, Budapest; Abb. 36) ${ }^{15}$ und die Federzeichnung der $\mathrm{Hl}$. Margareta von Antiochien (Museum der Schönen Künste, Budapest; Abb. 37) ${ }^{16}$ erwähnen. Diese schönsten Kunstwerke der ungari-

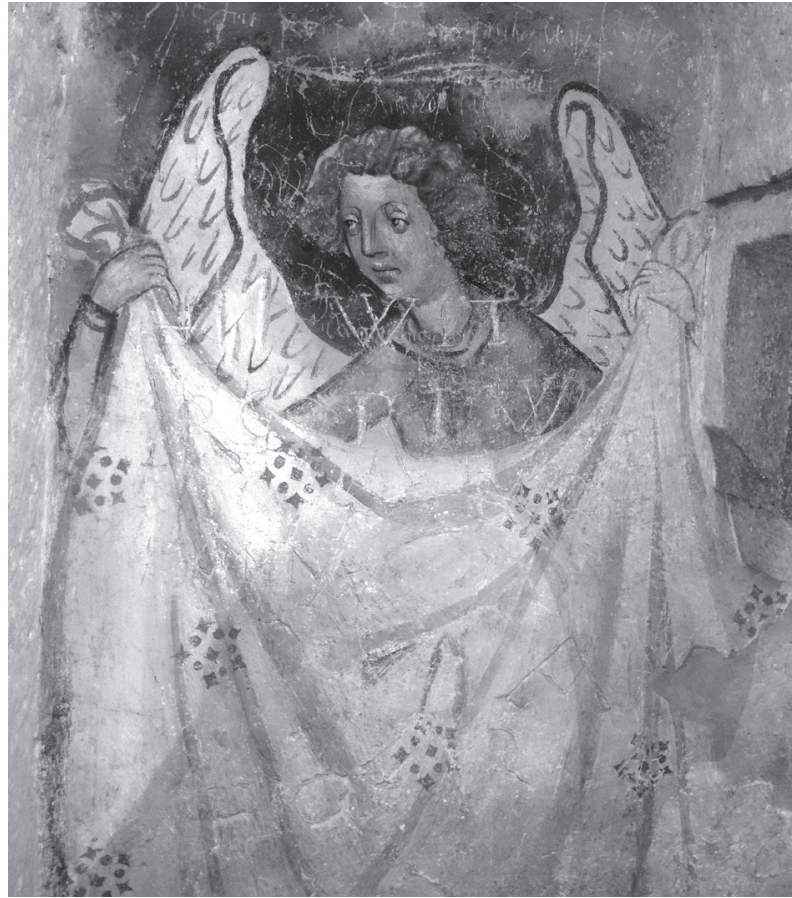

Abb. 29. Engel in der Sitznische der Südwand des Chores, nach der Restaurierung (Foto: Pál Lóvei) 


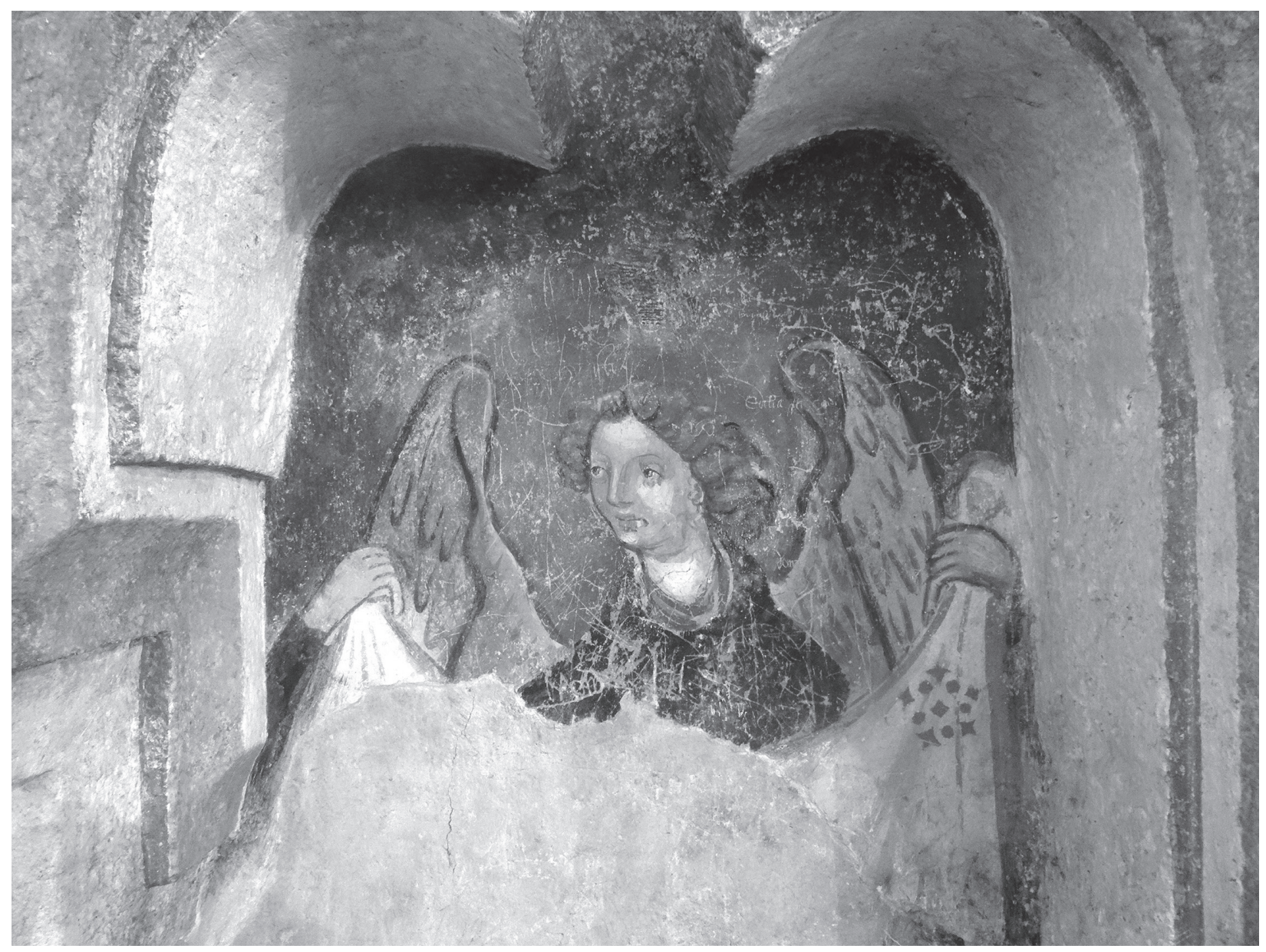

Abb. 30. Engel in der Sitznische der Südwand des Chores, nach der Restaurierung (Foto: Pál Lôvei)

schen Internationalen Gotik sind in der Fachliteratur wohlbekannt.

Die neu aufgefundenen Fresken von Torna, die von einem hohen ungarischen Würdenträger des Budaer Hofes von Sigismund, Paulus Özdögei Besenyô, bestellt worden waren, geben zu den oben erwähnten Kunstwerken ein weiteres wunderbares Beispiel hinzu, welches die Forschungsergebnisse von Prof. Michael Viktor Schwarz neu bestätigt, wonach Sigismunds Budaer Hof eines der wichtigsten Zentren der Internationalen Gotik war.

Warum vollzog sich die rasche und tiefgehende Stilwandlung vom Trecento-Stil zur Internationalen Gotik in Ungarn in der höfischen Kunst von Sigismund am Anfang des 15. Jahrhunderts? Es ist wohlbekannt, dass kurz zuvor, während des ganzen 14. Jahrhunderts, während der Regierung der neapolitanischungarischen Anjous in Ungarn, die Trecento-Züge sehr stark die Kunst charakterisiert hatten, besonders in der Wandmalerei. ${ }^{17}$ Als Antwort lassen wir einen Blick auf die Wandmalerei des Komitats Gömör wer- fen. ${ }^{18}$ Dies war ein mit dem Komitat Torna benachbartes Gebiet.

Der Besitzer der Gegend von Torna und Gömör war seit 1243 die Familie Bebek von Pelsôc (heute Plešivec, Slowakei) aus dem Komitat Gömör. Die Familie Bebek war im 14. Jahrhundert, während der Zeit der Anjoukönige, eine der größten adeligen Familien des Königreichs Ungarn. Die auch heute noch stehenden Kirchen ihres einstigen Sitzes im Komitat Gömör sind mit qualitätsvollen Fresken aus dem 14. Jahrhundert dekoriert. Besonders die Ausstattungen der Kirchen von Pelsốc und Csetnek (heute Štitnik, Slowakei) beweisen ihre hervorragende Kultur. Lassen wir uns nur an die merkwürdigen Fresken vom christologischen Zyklus von Pelsốc erinnern. Die am besten erhaltene Darstellung, Die Darbringung Jesu im Tempel, ist eine prachtvolle Trecento-Komposition von der Mitte des 14. Jahrhunderts. Ebenso die gotischen Fresken in der Kirche von Süvete (heute Šivetice, Slowakei) im Besitz der Familie Jolsvai und die schönen Fresken in der Kirche von Karaszkó (heute Kraskovo, 


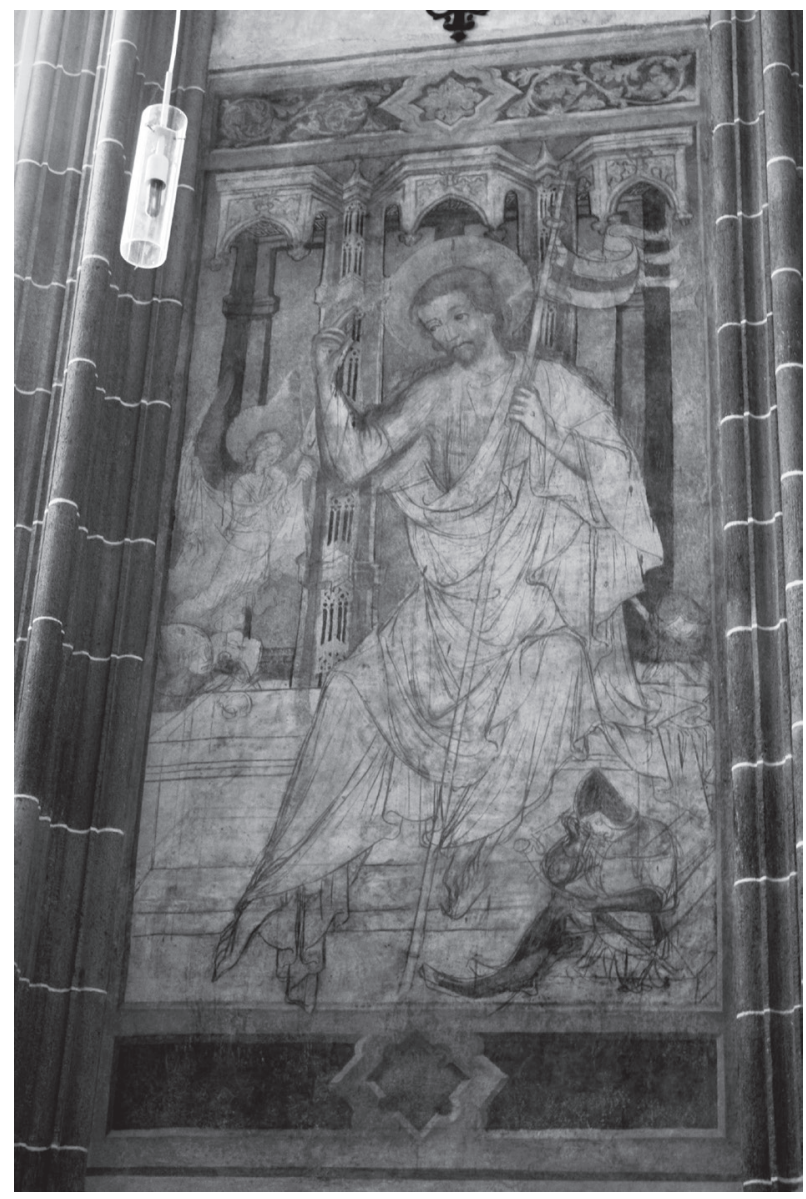

Abb. 31. Auferstehung Christi, Fresko in der Elisabethkirche von Kaschau (Kassa, Košice, Slowakei) (Foto: Zsombor Jékely)

Slowakei) aus dem Jahr 1370 im Besitz der Familie Szécsényi.

In der Stadt Csetnek, wo die Residenz der Familie Csetneki war (welche aus der Familie Bebek entstammte), sind in der großen dreischiffigen Pfarrkirche die Überreste von Fresken aus drei Perioden des 14.-15. Jahrhunderts sichtbar. So kann man die Veränderung des Stils der künstlerischen Darstellungen gut erkennen und datieren. Die Fresken im nördlichen Nebenschiff stammen aus dem 14. Jahrhundert und sind im Trecento-Stil dargestellt. Die Verkündigung Marias, die Allegorien der Sieben Freien Künste und die Szenen der Sieben Sakramente sind schöne Kunstwerke des Internationalen Stils, welche fünfzig Jahre später, um 1420, von Ladislaus Csetneki bestellt worden waren. Letzterer war Propst des Kapitels von Esztergom, zugleich auch Administrator des Erzbistums Esztergom und Kanzler der Königin Barbara. Ebenda zeigen die Szenen der Parabel über die Talente stilistische Verbindungen mit der lombardischen Internatio-

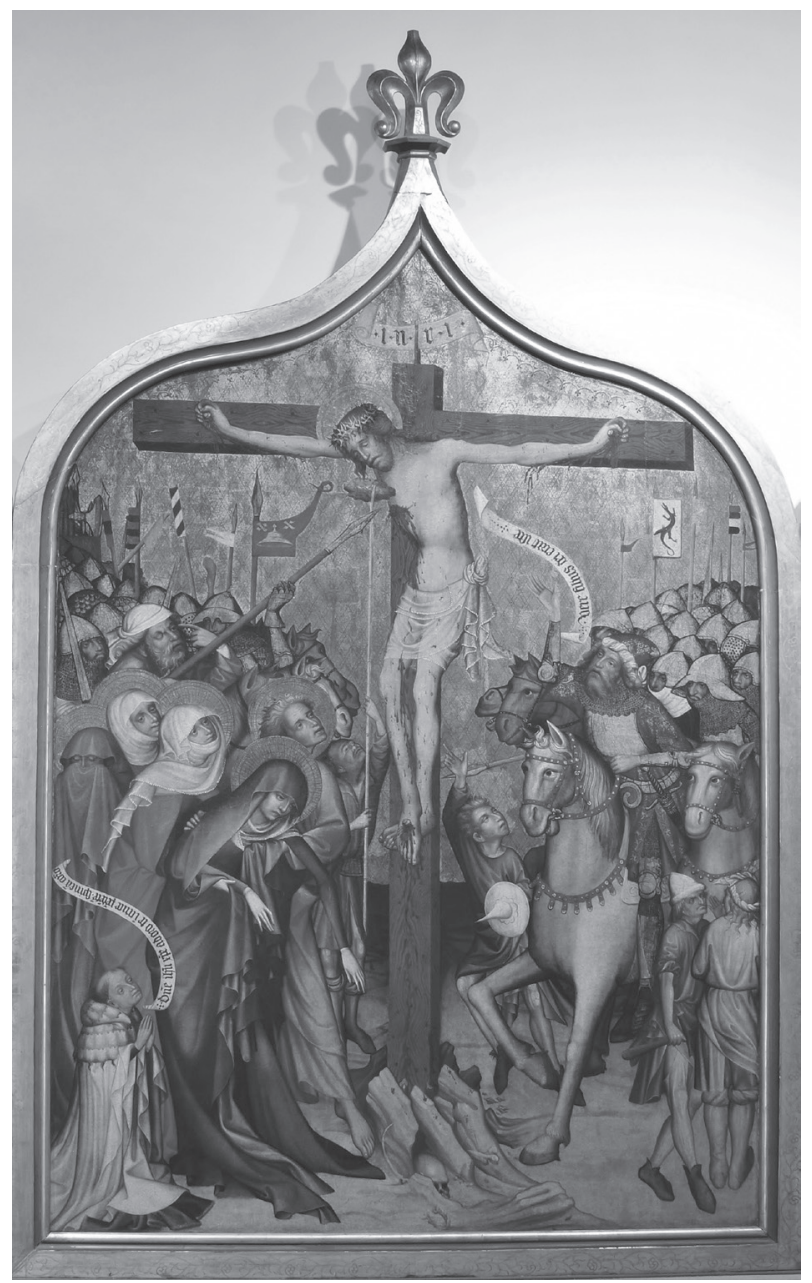

Abb. 32. Kalvarienaltar von Thomas de Koloswar, 1427. Christliches Museum, Esztergom (Foto: Attila Mudrák)

nalen Gotik, mit der Kunst von Masolino da Panicale, der in den Jahren 1424-1427 für den Herrn Magnificus Filippo Scolari, Mitglied des Drachenordens, in Ungarn gearbeitet hat. Er hat die Ausstattung der Kapelle Brancacci unterbrochen und eine Einladung nach Ungarn angenommen. Hier hat er seinen nächsten Mäzen, den Kardinal Branda Castiglione von Castiglione d'Olona, kennengelernt.

Die Veränderung des Stils um 1400 in Richtung Internationale Gotik charakterisierte die Kunst in ganz Europa, deshalb hat sie diesen Namen bekommen. In Ungarn hatte diese Wandlung aber auch eine politische Komponente. Sigismund wurde als Gemahl der Königstochter Maria von Anjou (†1395) 1387 zum König von Ungarn gekrönt. Ein Teil der Würdenträger des königlichen Hofes, besonders die Herren von Südungarn, Kroatien und Dalmatien, wollten aber eher einen Anjoukönig am Thron sehen. Am Anfang seiner Herrschaft hatte Sigismund deshalb Schwierigkeiten, seine Macht in Ungarn zu konsolidieren. So konnte es vorkommen, 


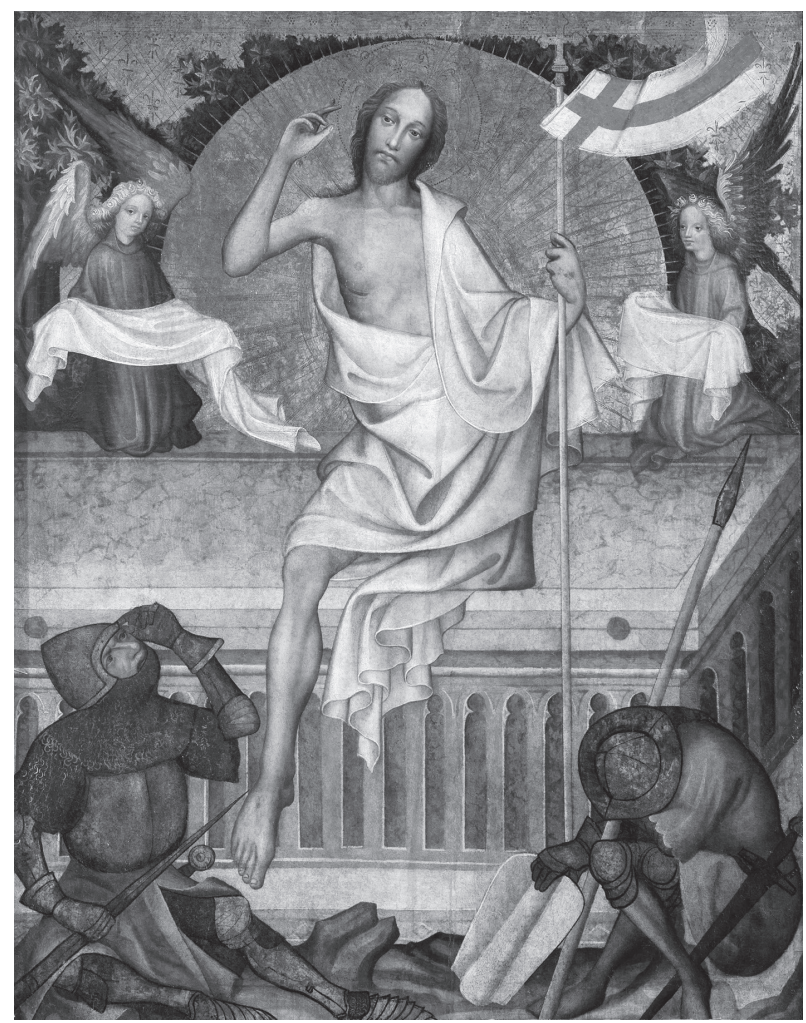

Abb. 33. Detail des Kalvarienaltars von Thomas de Koloswar: Auferstehung Christi, 1427 (Foto: Attila Mudrák)

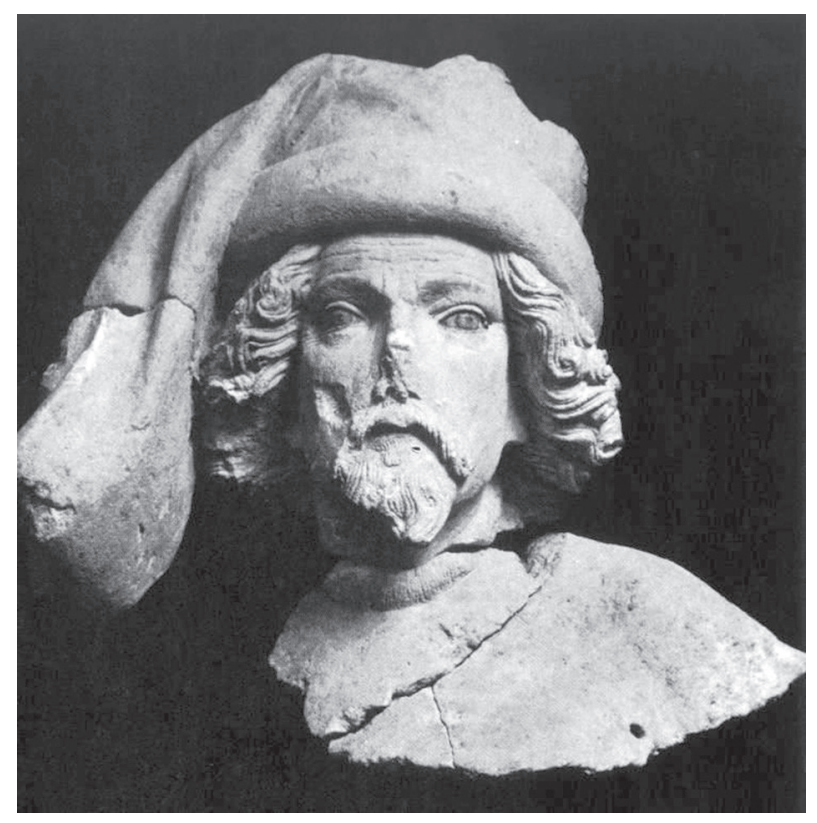

Abb. 34. Ritter aus dem sog. Budaer Skulpturenfund. Historisches Museum der Stadt Budapest

dass die Herren von Gara und Cille (heute Celje, Slowenien) ihn 1401 gefangen genommen hatten. Aus dem Kerker konnte er sich nur mit einem Kompromiss befreien: Er hat die Tochter des slawonischen Herrn

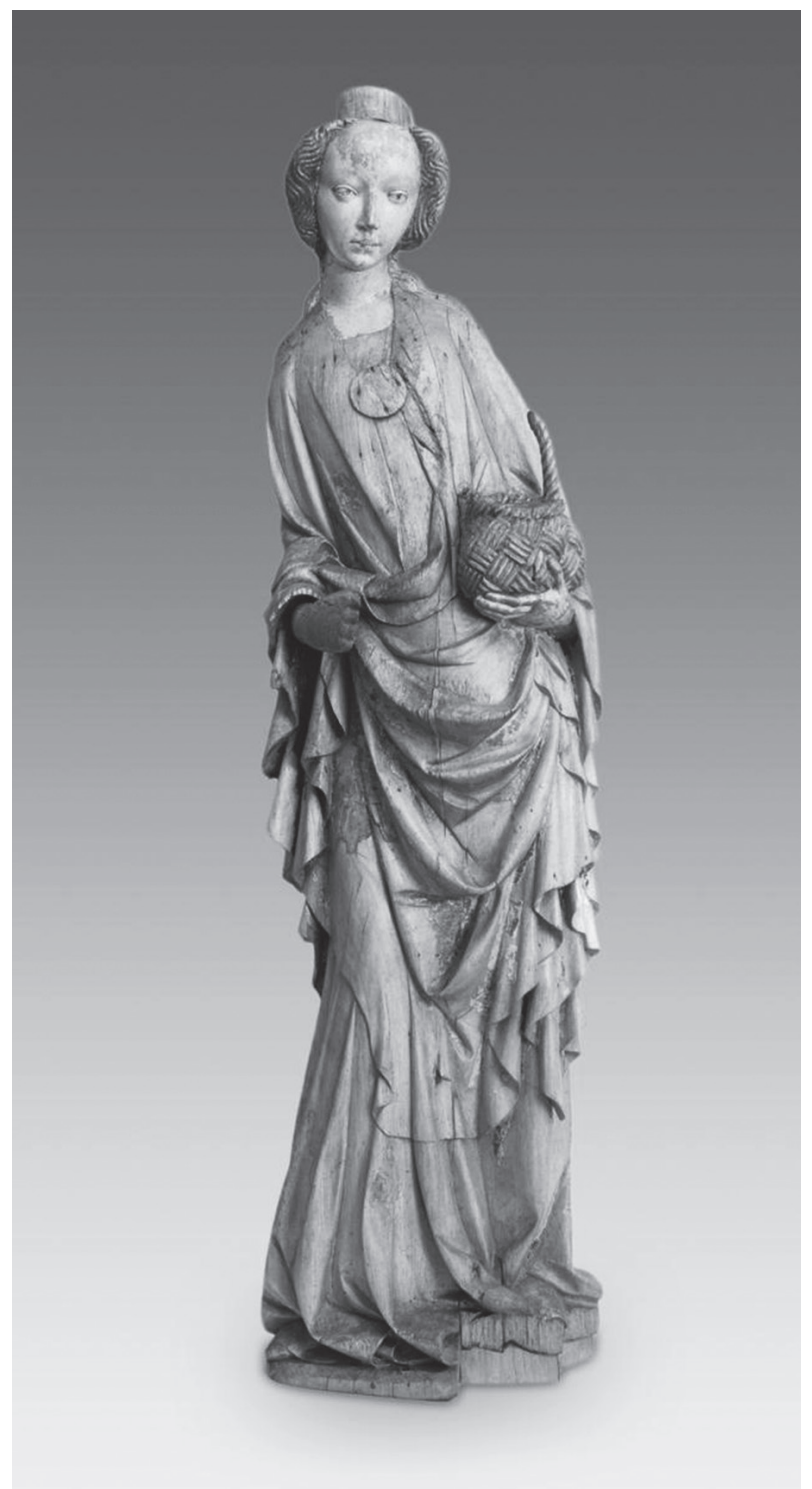

Abb. 35. Hl. Dorothea von Barka (Bôrka, Slowakei), 1420er Jahre. Budapest, Ungarische Nationalgalerie - Museum der Schönen Künste

von Cille, Barbara, zur Frau genommen. Die Ehe wurde 1405 geschlossen. In der Zwischenzeit, als sich Sigismund eben in Böhmen aufhielt, hatten die Anhänger der Anjou-Familie den neapolitanischen König Ladislaus von Anjou (1387-1414) nach Ungarn gerufen, wo er in der dalmatinischen Küstenstadt Zara (Zadar, Kroatien) am 5. August 1403 vom Erzbischof von Esztergom, dem Primas von Ungarn, Sigismunds Kanzler, Johannes Kanizsai, zum König von Ungarn gekrönt wurde. Der General von Sigismund, der Herr Stibor von Stiboric und der Palatin Nikolaus II. Garai unterdrückten aber den Aufstand. König Sigismund vergab den Rebellen und gründete 1408 einen neuen Orden, den Drachenorden, für seine treuesten Männer. ${ }^{19}$ 


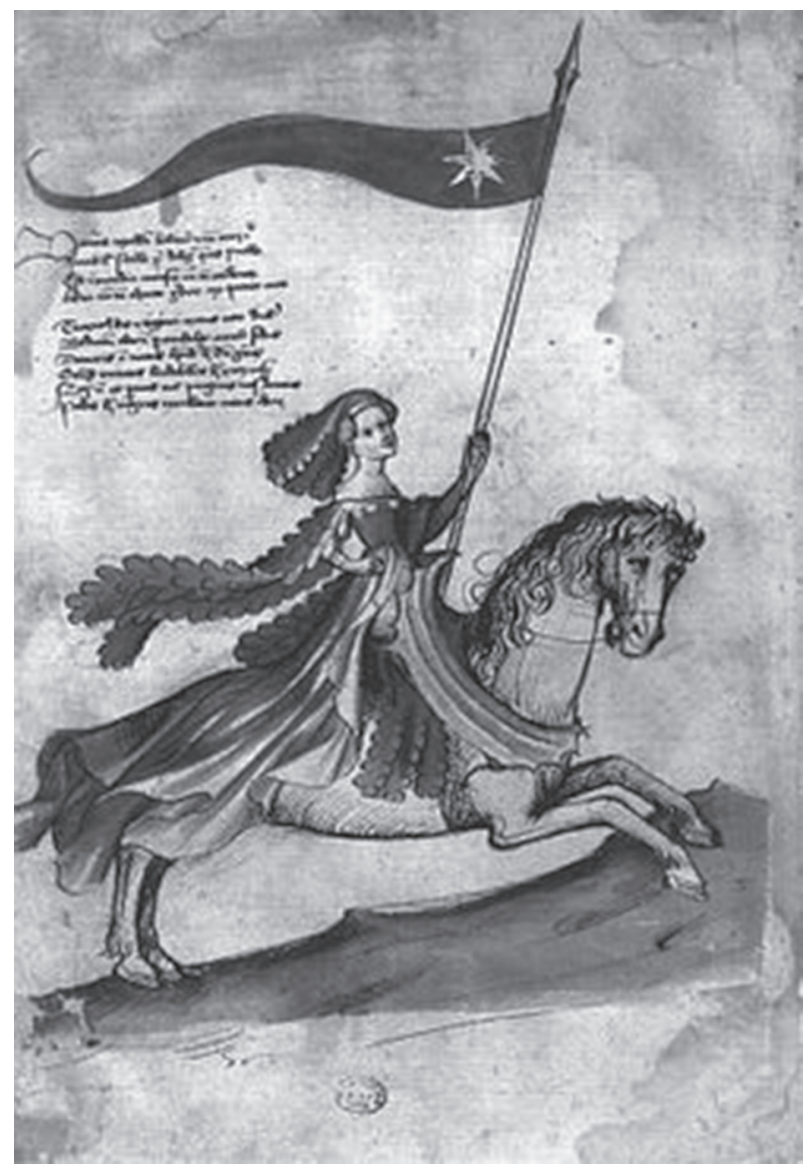

Abb. 36. Triumphzug der Königin Barbara, Bellifortis Liber de septem signis, Aquarell. Budapest, Bibliothek der Ungarischen Akademie der Wissenschaften

Die Kenntnis über diese historischen Umstände kann uns helfen, die rasche Veränderung des künstlerischen Stils in Ungarn um 1410 zu verstehen. Diese historischen und politischen Umstände sollen wir bei der Datierung der Kunstwerke aus dem Kreis Sigismunds in Betracht nehmen. Die Stilwandlung war ein wichtiges Mittel für Sigismund, um seine Macht zu stärken. Der neue internationale gotische Stil war ein Zeichen der Loyalität zu ihm am Anfang des 15. Jahrhunderts.

Nach 1410, als Sigismund auch deutscher König wurde, und später, als er 1433 in Rom von Papst Eugen IV. auch zum römisch-deutschen Kaiser gekrönt wurde, erstreckte sich seine Wirkung über fast ganz Europa. Seine Hauptresidenz blieb aber während seines ganzen Lebens Buda. Nach seinem Tod wurde er 1437 seinem Testament entsprechend in Ungarn, in der Kathedrale von Várad (heute Oradea, Rumänien), neben seinem Vorbild, dem Hl. Ladislaus, und seiner ersten Frau, Maria von Anjou, beigesetzt. ${ }^{20}$

Die Gegend des Komitates Torna - wie ganz Oberungarn, das seit 1993 Slowakei heißt - ist für die

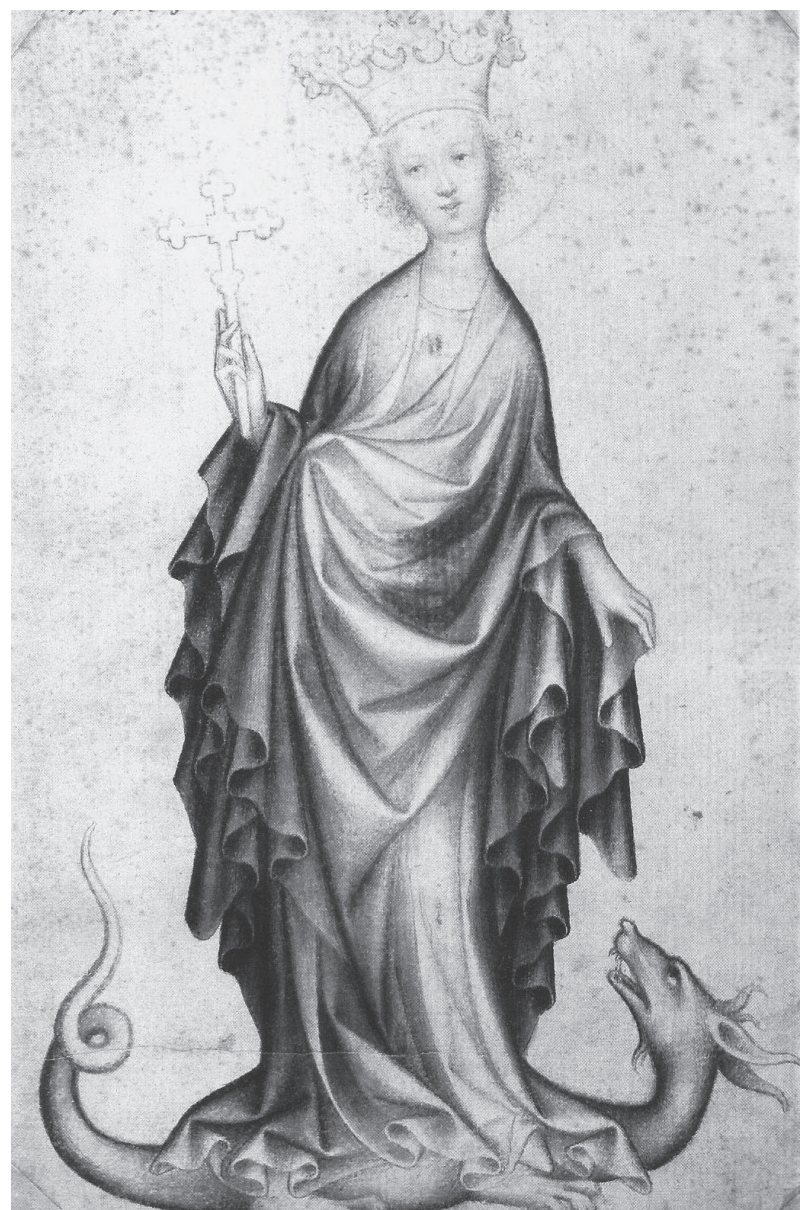

Abb. 37. Die Hl. Margareta von Antiochien, Federzeichnung. Budapest, Museum der Schönen Künste

ungarische Kunstgeschichte sehr wichtig, weil dieser Teil des Königreichs Ungarn zwischen 1526 und 1686 nicht von den muslimischen Türken erobert war, sodass hier die christlichen Denkmäler des Mittelalters nicht zerstört wurden. Diese Gegend von Oberungarn blieb ein Teil des Königreichs Ungarn während der Osmanenzeit. Die Krönungen der Könige fanden zwischen 1563 und 1830 in der zur Diözese Esztergom gehörenden Propsteikirche von Pressburg statt. Auch der Erzbischof von Esztergom, der Primas von Ungarn, der Stellvertreter des Königs, residierte zwischen 1543 und 1820 in Tirnau (Nagyszombat, heute Trnava, Slowakei), nicht weit von Pressburg.

2017 fand eine Konferenz in Torna über die neuen Forschungsergebnisse der Kirche statt. Sie wurde vom gelehrten Pfarrer Dr. Attila Juhász und vom Bürgermeister organisiert. Die besten Fachleute aus der Slowakei und Ungarn - die nun durch die neu entdeckten Schätze der dortigen Kirche verbunden sind - hielten Vorträge, welche bald publiziert werden sollen. ${ }^{21}$ 


\section{ANMERKUNGEN}

${ }^{1}$ Engel, Pál: Magyarország világi archontológiája 13011457 [Weltliche Archontologie Ungarns 1301-1457], Budapest, 1996. I. 445.

2 JuHÁsz, Attila: A tornai plébánia története [Die Geschichte der Pfarrei Torna], Kassa, 2002.

${ }^{3}$ LôvEI, Pál: A tornai római katolikus templom középkori sírkövei [Die mittelalterlichen Grabsteine der katholischen Kirche von Torna], JAMÉ - A Nyíregyházi Jósa András Múzeum Évkönyve [Annales des Jósa-András-Museums in Nyíregyháza] LIX. I. 2017. 135-144.

${ }^{4}$ ENGEl 1996 (vgl. Anm. 1), I. 445; II. 35.

${ }^{5}$ LÔVEI, Pál: Néhány címeres emlék a 14-15. századból [Einige Objekte mit Wappen aus den 14.-15. Jahrhunderten], Müvészettörténeti Értesítô XL. 1991. 49-51, Abb. 1-4.

${ }^{6}$ KRCHO, János - Gomboš, Peter: A tornai Nagyboldogasszony-templom középkori falfestményei és építészettörténeti összefüggései [Die mittelalterlichen Fresken und die baugeschichtlichen Zusammenhänge der Liebfrauenkirche in Torna], in Regionális európai kapcsolatok Kelet-KözépEurópa középkori falfestészetében, 2009. április 23-25., Balatonfüred [Regionale europäische Beziehungen in der mittelalterlichen Wandmalerei Ostmitteleuropas], Resumees der Tagung, 2009. 22; JÉKelY, Zsombor: Painted Chancels in Parish Churches - Aristocratic Patronage in Hungary during the Reign of King Sigismund (1387-1437), in Hungary in Context. Studies on Art and Architecture, eds. TüskÉs, Anna Tóth, Áron - Székely, Miklós, Budapest, 2013. 51-52, Figs. 6-8; KRCHO, János: A tornai Nagyboldogasszony-templom szentélyének felújítása [Erneuerung des Chors der Liebfrauenkirche in Torna], Épitész Közlöny 2018/5. 10-11.

${ }^{7}$ Sigismundus Rex et Imperator. Kunst und Kultur zur Zeit Sigismunds von Luxemburg, 1387-1437. Ausstellungskatalog Budapest-Luxemburg 2006, hrsg. von TAKÁCS, Imre, Mainz am Rhein, 2006. 377-378 (Kat.-Nr. 4.90; Kiss, Etele).

${ }^{8}$ Johannes Aquila und die Wandmalerei des 14. Jahrhunderts. Tagungsbeiträge und Dokumente aus den Sammlungen des Landesdenkmalamtes Budapest / Johannes Aquila és a 14. század falfestészete. Tanulmányok és dokumentumok a budapesti Országos Múemléki Felügyelôség gyưjteményéból, hrsg. von Marosi, Ernó, Budapest, 1989. Abb. 115-120.

9 JuHÁsz 2002 (vgl. Anm. 2), 24-25.

10 JuCKES, Tim: The Parish and Pilgrimage Church of St Elizabeth in Kosice - Town, Court, and Architecture in Late Medieval Hungary, Turnhout, 2012.
11 Sigismundus 2006 (vgl. Anm. 7), 580-586 (Kat.-Nr. 7.19; Poszler, Györgyi).

12 MAROSI, Ernô: Vorläufige kunsthistorische Bemerkungen zum Skulpturenfund von 1974 in der Burg von Buda, Acta Historiae Artium 22. 1976. 333-374; MAROSI, Ernó: Die Skulpturen von Buda im europäischen Kontext, in Das Konstanzer Konzil 1414-1418. Große Landesausstellung des Badischen Landesmuseums Karlsruhe, hrsg. von BraUn, Karl-Heinz, I. Darmstadt, 2013. 175-181; PAPP, Szilárd: A király mûhelye: Luxemburgi Zsigmond budavári szobrai és mûvészettörténeti helyzetük [The Workshop of the King: The Buda-Castle Sculptures of Sigismund of Luxembourg and their Place in Art History], Mũvészettörténeti Értesítô 63. 2014. 1-37.

${ }^{13}$ SCHWARZ, Michael Viktor: Höfische Skulptur im 14. Jahrhundert. Entwicklungsphasen und Vermittlungswege im Vorfeld des Weichen Stils, Worms, 1988.

${ }^{14}$ Sigismundus 2006 (vgl. Anm. 7), 576 (Kat.-Nr. 7.1213; VERÓ, Mária).

15 Sigismundus 2006 (vgl. Anm. 7), 397-398 (Kat.-Nr. 4.107; MAROSI, Ernô).

${ }^{16}$ Sigismundus 2006 (vgl. Anm. 7), 592-593 (Kat.-Nr. 7.28; Koreny, Fritz).

${ }^{17}$ Prokopp, Mária: Italian Trecento Influence on Murals in East Central Europe, particularly Hungary, Budapest, 1983.

18 Zusammenfassend: Prokopp, Mária: Medieval frescoes in the Kingdom of Hungary, Šamorín, 2005; ProKopp, Mária: Affreschi medievali nella regione di Gömör del regno d'Ungheria, Somorja, 2005.

${ }^{19}$ KovÁcs, Éva: The Chivalric Order of the Dragon, The New Hungarian Quarterly 29. 1988. (Nr. 110) 102-105; LÓVEI, Pál: Der ungarische Drachenorden, in Die Ritter, Burgenländische Landesausstellung 1990, Burg Güssing, Eisenstadt, 1990. 64-67; LôvEI, Pál: Hoforden im Mittelalter unter besonderer Berücksichtigung des Drachenordens, in Sigismundus 2006 (vgl. Anm. 7), 251-263.

${ }^{20}$ Kerny, Terézia: Begräbnis und Begräbnisstädte von König Sigismund, in Sigismundus 2006 (vgl. Anm. 7), 475479 .

${ }^{21}$ Sprachlektor: Péter Schmidt. AAlle namentlich nicht gekennzeichneten Fotos über die Wandmalereien der Pfarrkirche von Torna stammen von Peter Gomboš oder von János Krcho. 